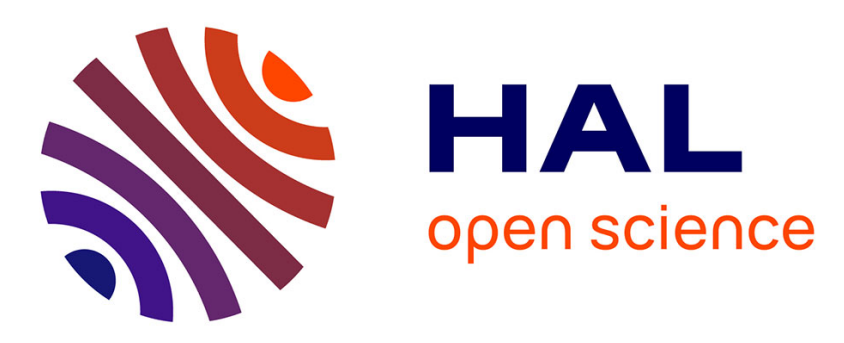

\title{
Fluid-rock interactions along detachment faults during continental rifting and mantle exhumation: the case of the Urdach lherzolite body (North Pyrenees)
}

\author{
Jehiel Nteme Mukonzo, Marie-Christine Boiron, Yves Lagabrielle, Michel
} Cathelineau, Benoit Quesnel

\section{To cite this version:}

Jehiel Nteme Mukonzo, Marie-Christine Boiron, Yves Lagabrielle, Michel Cathelineau, Benoit Quesnel. Fluid-rock interactions along detachment faults during continental rifting and mantle exhumation: the case of the Urdach lherzolite body (North Pyrenees). Journal of the Geological Society, 2021, 178 (2), pp.jgs2020-116. 10.1144/jgs2020-116 . insu-03123590

\section{HAL Id: insu-03123590 \\ https://hal-insu.archives-ouvertes.fr/insu-03123590}

Submitted on 14 Oct 2021

HAL is a multi-disciplinary open access archive for the deposit and dissemination of scientific research documents, whether they are published or not. The documents may come from teaching and research institutions in France or abroad, or from public or private research centers.
L'archive ouverte pluridisciplinaire HAL, est destinée au dépôt et à la diffusion de documents scientifiques de niveau recherche, publiés ou non, émanant des établissements d'enseignement et de recherche français ou étrangers, des laboratoires publics ou privés. 
Fluid-rock interactions along detachment faults during continental rifting and mantle exhumation: the case of the Urdach Iherzolite body (North-Pyrenees)

\author{
Jehiel NTEME MUKONZO ${ }^{1}$, Marie-Christine BOIRON ${ }^{2 *}$, Yves LAGABRIELLE ${ }^{1}$, Michel \\ CATHELINEAU ${ }^{2}$, Benoit QUESNEL ${ }^{2-3}$.
}

1-Université de Rennes, CNRS, UMR 6118 Géosciences Rennes, Campus de Beaulieu, 35000 Rennes, France

2- Université de Lorraine, CNRS, CREGU, GeoRessources, F-54000 Nancy, France 3- Present address : Département de géologie et génie géologique, Université Laval, Pavillon Adrien-Pouliot, 1065 av. de la Médecine, Québec G1V 0A6, Canada

* Corresponding author: Marie-christine.boiron@univ-lorraine.fr

Journal of the Geological Society of London 


\section{ABSTRACT}

The North Pyrenean Zone (NPZ) corresponds to the paleo-passive margin of the North Iberia plate at the foot of which subcontinental mantle exhumed during Albian times. Rare bodies of exhumed mantle rocks associated with strongly sheared lenses of continental crust are scattered among the NPZ metasediments. In the Urdach massif (Chaînons Béarnais), significant fluid flow occurred along a major décollement at the basement-Trias interface. Fluids with a broad range of salinity (10 to 38 wt.\% $\mathrm{NaCl}$ equiv.), indicative of mixing between brines and more diluted waters, produced strong silicification of breccias. Brines circulated at around $240-280^{\circ} \mathrm{C}$ under lithostatic pressures at about 6 $\pm 1 \mathrm{~km}$ depth. Fluids became increasingly saline towards the final stages. Then, the syn-deposition of Cenomano-Turonian flysch layers progressively isolated the lower aquifers close to the décollement where Triassic brines were predominant. The release and the migration of significant volumes of brines during the stretching and squeezing of the Triassic evaporites played a critical role in the mineralogical and rheological transformations that occurred during the Pyrenean Cretaceous rifting event.

Keywords: Fluid inclusions, Brines, Triassic evaporites, Detachment fault, Passive margin, Pyrenees 


\section{Introduction}

The exhumation of subcontinental mantle rocks in the axial portions of the Pyrenean and periPyrenean smooth-slopes basins drove intensive fluid circulation, which subsequently may yield strong fluid-rock interactions, such as active serpentinization of the uprising peridotites (Agrinier et al., 1988; Mével, 2003; Karson et al., 2006; Boschi et al., 2013; Pinto et al., 2015, Lagabrielle et al., 2020) and carbonation of the exhumed ultramafic basement (Alt and Shanks, 2003; Ludwig et al., 2006; Lafay et al., 2017 and references therein). These processes are responsible for significant mass and heat transfer concentrated along the long offset extensional detachment faults accommodating mantle exhumation (Picazo et al., 2012; Lagabrielle et al., 2019a; 2019b).

Fluid circulations in magma-poor passive margins are still poorly investigated since they develop in deep seafloor environments and at various levels of the stretched lithosphere. Recent studies focused on fluid-rock interactions in fossil passive margin systems of orogenic belts such as those preserved in the Alps and Pyrenees (Fallourd et al., 2014; Pinto et al., 2015; Corre et al., 2018; Quesnel et al., 2019, Incerpi et al., 2019, 2020). Along the northern flank of the Pyrenean belt, the North Pyrenean Zone (NPZ) hosts well-preserved remnants of inverted mid-Late Cretaceous basins including exhumed Iherzolitic mantle fragments (Lagabrielle and Bodinier, 2008; Jammes et al., 2009; Lagabrielle et al., 2010; Clerc and Lagabrielle, 2014; Corre et al., 2016). Large fluid circulations at a regional scale have been synchronous with the extensional Cretaceous phase in the NPZ, with the significant formation of secondary mineral assemblages. Among the latter, the albitization of the plutonic basement (Boulvais et al., 2007; Poujol et al., 2010) and Mg-rich metasomatism yielding to talc-chlorite assemblages in regional-scale detachment faults are the most representative (Moine et al., 1989, Schärer et al., 1999, Boulvais et al., 2006; Boiron et al., 2007, Corre et al., 2018, Quesnel et al., 2019). During the formation of the rifted margins, the pre-rift sediments were detached from their Paleozoic basement along the Keuper evaporite levels (Teixell et al., 2016). Consequently, due to the lateral extraction of the hyperthinned continental crust accompanying mantle exhumation (Clerc and Lagabrielle, 2014), the uplifted Iherzolites tectonically underlie the detached pre-rift cover in the central part of the Cretaceous basins.

Well preserved remnants of original low angle fault zones separating the mantle rocks from the detached pre-rift sedimentary cover are exposed in some localities along the NPZ. In the Chaînons Béarnais (western NPZ), the Saraillé and Urdach mantle bodies were studied in detail (Corre et al., 2016; 2018; Asti et al., 2019; Lagabrielle et al., 2019 a, b). The Urdach Iherzolites are associated with an ultramafic-felsic breccia interfingered with syn-rift flysch layers of Late Albian age (Urdach breccia: Casteras et al., 1970; Debroas et al., 2010). This breccia was emplaced over the exhumed mantle 
rocks and locally constitutes the early sedimentary cover of the peridotites and associated sheared Paleozoic rocks.

Studying the hydrothermal systems in inverted rifts or passive margins provides essential constraints on the mass transfer and thermal gradients linked to subcontinental mantle exhumation. This allows the reconstruction of the diagenetic and thermal evolution of sedimentary syn-rift successions capping these structures. In this paper, we investigate the fluid circulations along two major detachment faults of the Urdach massif through a fluid inclusion study. At first, we present the results of microthermometry and Raman spectroscopy analyses of fluid inclusions, and then we discuss the origin of fluids and the P-T conditions of their circulation. We finally propose a conceptual model of fluid flow events in the zone of decoupling between exhumed subcontinental mantle, paleozoic basement and pre-rift cover from the inverted North Iberia passive margin.

\section{Geological setting}

The Pyrenean belt, the NPZ, and the Chaînons Béarnais range

The Pyrenees (Fig. 1) is an E-W trending belt corresponding to a shortened crustal domain resulting from the collision of the northern edge of the Iberia Plate and the southern edge of the Eurasia Plate during the late Cretaceous and the Tertiary (Choukroune and ECORS Team 1989; Muñoz 1992; Deramond et al. 1993; Roure and Choukroune 1998; Teixell 1998). Cretaceous rifting occurred in the Pyrenean domain in response to the counterclockwise rotation of Iberia relative to Eurasia, coeval with the onset of oceanic spreading in the Bay of Biscay between Chron M0 and A33o (approximately 125-83 Ma) (Le Pichon et al. 1970; Choukroune and Mattauer 1978; Olivet 1996; Gong et al. 2008; Jammes et al., 2009). This rifting is characterized by an extreme thinning of the continental crust leading to the local exhumation of subcontinental mantle rocks to the floor of Albian-Cenomanian basins. The tectonic inversion of these basins resulted in the stacking of units forming the present-day NPZ (Choukroune and ECORS Team 1989; Munoz, 1992; Vacherat et al., 2016; Teixell et al., 2018; Espurt et al., 2019) (Fig. 1). The NPZ is characterized by high-temperature low-pressure (HT-LP) metamorphism with decreasing intensities from $\mathrm{E}$ to $\mathrm{W}$. This metamorphism developed from 110 to $80 \mathrm{Ma}$ (Golberg and Leyreloup, 1990, Clerc et al., 2015) and is well recorded in pre-rift and basal syn-rift metasediments (Dauteuil and Ricou, 1989; Clerc et al., 2013; Corre et al., 2016, Incerpi et al., 2020). As a response to elevated thermal conditions, crustal thinning along the future NPZ occurred in a dominately ductile mode involving lateral extraction of the stretched crustal basement. This led to the opening of basins characterized by symmetrical smooth-slope conjugate margins (Clerc and Lagabrielle, 2014; Teixell et al., 2016; Lagabrielle et al., 2020). 
The Chaînons Béarnais range corresponds to a segment of the west-central NPZ, forming a series of three E-W-trending fold-thrust structures made of the Mesozoic sediments. From north to south they are: the south-verging Mail Arrouy thrust, the Sarrance anticline and the north-verging Layens anticline (Castéras et al., 1970) (Fig. 2). The base of the Mesozoic sequence is represented by an incomplete and strongly deformed Triassic succession ending with Keuper facies composed of shales, evaporites, breccias, and ophites. It is followed by Jurassic to Aptian platform limestones and dolomites with shale intercalations in the Upper Liassic and Lower Aptian. These sediments represent the original pre-rift cover of the northern Iberian margin (Canérot and Delavaux, 1986; Canérot et al., 1978), now entirely detached from its original Palaeozoic basement (Lagabrielle et al., 2010; Teixell et al., 2016).

\section{The Urdach massif}

The Urdach massif (Fig. 3) is located at the western termination of the Mail Arrouy thrust sheet and can be considered as part of the easternmost border of the Mauléon Basin, which opened after the break down of the Aptian Urgonian-type platform. There, more than $5000 \mathrm{~m}$ of turbidites accumulated during the Late Cretaceous (Canérot, 2017, and references herein). The Urdach massif consists of a lens-shape body of serpentinized Iherzolites tectonically associated with Mesozoic carbonates and thin units of Paleozoic basement. The Urdach lens axis is oriented NW-SE, with a length of around $1,5 \mathrm{~km}$ and a width of approximately $1 \mathrm{~km}$. It is bounded to the west by large exposures of the verticalized syn-rift flysch of Albian to Cenomanian age (Casteras et al., 1970). The Paleozoic units are welded on the western, southern, and eastern borders of the mantle body and include various variscan lithologies such as gneiss, micaschist, quartzite, and granitoid (Corre, 2017). All these lithologies suffered intense deformation due to displacement along a detachment fault during mantle exhumation and most often display a mylonitic foliation parallel to their limit with the mantle body (Asti et al., 2019). On its western side, the Urdach massif is partially covered by the verticalized Urdach sedimentary breccia, as shown in the geological section of figure 3 . The Urdach breccia is a 200 to $1000 \mathrm{~m}$ thick formation (Debroas et al., 2010) which comprises a succession of debris flows composed of clasts of Paleozoic continental rocks, ultramafic rocks and minor Mesozoic carbonates in a flysch matrix containing microfauna of Late Albian and Early Cenomanian age (Roux, 1983, Souquet et al., 1985, Debroas et al., 2010). The presence of mantle rock fragments in the Urdach breccia indicates that the Iherzolites were brought to the surface during the AlbianCenomanian period. By analysing the deformation of Paleozoic clasts from the Urdach breccia, Asti et al. (2019) propose that the exhumation of the Urdach mantle coevally occurred with extreme thinning and ductile deformation of the continental crust under greenschist metamorphic facies conditions. Necking of the lower crust allowed the middle crust to come into tectonic contact with 
the lithospheric mantle. This deformation has been dated at $105.2 \pm 0.5 \mathrm{Ma}$ by the ${ }^{40} \mathrm{Ar}-{ }^{39} \mathrm{Ar}$ method on a large mica fish muscovite in a mylonitic leucocratic gneiss from a crustal unit exposed on the eastern side of the Urdach body, at Col d'Urdach (Asti el al., 2019).

\section{Geology of the sampling sites}

In the Urdach massif, several damaged zones around faults or lithological contacts are characterized by significant alteration and brecciation along two major Cretaceous discontinuities, which accommodated significant displacement during the Cretaceous extension of the Pyrenean rift. These are: (1) the crust-mantle detachment separating the mantle rocks from the Paleozoic basement and the base of the Urdach breccia close to Col d'Etche and (2) the cover décollement separating the detached Mesozoic cover from the mantle rocks close to Col d'Urdach (see location in Fig. 3) (Lagabrielle et al., 2019a; 2019b). These zones are fluid pathways which contain a good record of the pressure and temperature paleo-conditions and nature of the percolating fluids, the main subject of the present work. Sampling was done accordingly on two main zones:

(1) In the northern part of the Urdach massif, near Mer de Her and Col d'Etche (Fig. 3), a thin tectonic lens of schistosed Silurian black schists rests on the western border of the Urdach Iherzolites. The N-S trending schistosity is dipping at a high angle to the $\mathrm{E}$ and is locally vertical. Along a trail south of Soum d'Ombret, the Iherzolites and the Silurian schists are in vertical contact with a chaotic assemblage of welded cataclastic blocks of continental material paralleling the base of the Urdach breccia. These blocks consist exclusively of Paleozoic quartzite, most probably of Ordovician age and therefore result from the brecciation of Ordovician quartzites along the detachment fault when they reached shallow crustal levels (Lagabrielle et al., 2019a). South of Mer de Her, the tectonic breccia is overlain by the first levels of the Urdach breccia of indisputable sedimentary origin. To the north, the contact with the Urdach breccia is not exposed, and layers of Albian flysch are observed in a depression between Mer de Her and Soum d'Ombrets (Fig. 3).

(2) A verticalized fault contact separating the Urdach Iherzolites from brownish Liassic dolomites and Mid-Jurassic black schists can be observed close to Col d'Urdach (fig. 4e, f, g), along a road entering the Bugangue Forest ("ball trap" site in Lagabrielle et al., 2019a) (Fig. 3). This contact is a few meters thick shear zone showing strong evidence of fluid-rock interactions and corresponds to the cover décollement (Lagabrielle et al., 2019a) (Fig. 4e, f). There, the serpentinized Urdach mantle is progressively enriched in calcite veins with a gradual transition to ophicalcites. Against the ophicalcites, the décollement comprises a series of cataclastic carbonate lenses invaded by calcite veins and separated by shear-zones filled by a combination of calcite and syn-kinematic chlorite (Fig. $4 \mathrm{~g})$. The serpentine- and chlorite-rich shear zones are N-S oriented and dip to the east at a high angle. The décollement itself passes laterally to an assemblage of tectonic lenses of intricated brown- 
orange dolomites and black limestones (see complementary data and mineral analyses in Lagabrielle et al., 2019a). At 20-30 m from the Iherzolites, the fault rocks are composed of quartz + calcite + fuchsite + chlorite. This metasomatic mineralogical assemblage is typical of listvenite, a metasomatic rock often found along the sole of ophiolitic sheets (Glennie et al., 1974). In such settings, the listvenite layer can reach $10 \mathrm{~m}$ in thickness. The formation of listvenite is a metasomatic process affecting a serpentine-rich protolith (Plissart et al., 2009). It involves three different geochemical reactions: 1) carbonation, 2) silicification, and 3) Cr-rich mica formation. P-T conditions for the formation of all listvenites worldwide correspond to the greenschist facies $\left(200^{\circ} \mathrm{C}<\mathrm{T}<400^{\circ} \mathrm{C}\right.$, $1<\mathrm{P}<3 \mathrm{kbar}$ ) (Halls and Zhao, 1995; Harlov and Austrheim, 2013).

\section{Material and methods}

\section{Sampling strategy and sample description}

The chosen samples are: (i) the silicified continental breccias from the crust-mantle detachment beneath the base of the Urdach breccia near Col d'Etche (Fig. 4a) and (ii) the cover décollement in the "ball trap" site at Col d'Urdach (see sample location in Fig. 3). Only three samples displaying suitable fluid inclusions were used in this work. Two samples from Col d'Etche are Ordovician quartzite clasts cemented by quartz and crosscut by numerous quartz veins (Etche 5) (Fig. 4 b, c) or containing large elongated geodes (Etche 4) (Fig. 4 d). Samples from the "ball trap" site were taken from multilayered fault rocks forming the cover décollement, composed of alternating calcite and serpentine-chlorite veins. Only one sample (URD E) was suitable for our study (Fig. 3 and 4 e, f,g).

Methods

Microthermometry was carried out on fluid inclusions using a Linkam ${ }^{\circledR}$ MDS600 heating-cooling stage, adapted to an Olympus ${ }^{\circledR}$ microscope at the GeoRessources laboratory in Nancy (France). The following microthermometric parameters have been measured: The eutectic temperature (Te) which depends on the nature of cations present in the aqueous phase, the ice melting temperature (Tm ice), the halite melting temperature (Tm halite), and the homogenization temperature (TH) which constitutes the minimum trapping temperature of the fluid.

The stage was calibrated using three standards: $\mathrm{CO}_{2}-\mathrm{H}_{2} \mathrm{O}$ inclusions in CAMPERIO quartz (Alps) $\left(\mathrm{T}_{\mathrm{m}}\right.$ $\mathrm{CO}_{2}$ : $-56.6{ }^{\circ} \mathrm{C}$, solid $\mathrm{CO}_{2}$ melting temperature), a pure $\mathrm{H}_{2} \mathrm{O}$ capillary $\left(\mathrm{Tm}\right.$ ice: $0.0{ }^{\circ} \mathrm{C}$ ), and a natural aqueous inclusion Ta $33.2\left(\mathrm{TH}: 164.0^{\circ} \mathrm{C}\right.$ and Te: $\left.-21.2{ }^{\circ} \mathrm{C}\right)$.

Raman spectroscopy was used to determine the nature of the volatile phases present in the inclusions and to estimate the salinity of the inclusions qualitatively. Analyses were carried out with a LabRAM HR spectrometer (Horiba Jobin Yvon) at GeoRessources in Nancy (France). For chlorinities, 
the method is based on the calibration of the modification of the Raman spectrum of the water band as a function of the concentration of the chloride solution (Dubessy et al. 2002). Increasing the salt concentration in the water causes a decrease in band intensity around $3200 \mathrm{~cm}^{-1}$, an increase in intensity around $3450 \mathrm{~cm}^{-1}$, and a small shift towards a higher frequency of the maximum intensity of the whole band, which are calibrated. This approach allows chlorinity estimation in particular when microthermometry is difficult to carry out. Isochores were calculated using the equations of Zhang and Frantz (1987).

A few geodic quartz were crushed and leached to measure $\mathrm{Cl} / \mathrm{Br}$ ratio and $\delta^{37} \mathrm{Cl}$ value following the methods already described in Quesnel et al. (2019).

\section{Results}

Quartz textures and fluid inclusion distribution in silicified basement breccia from the detachment: Breccia blocks from Mer de Her consisting of silicified Paleozoic quartzite were studied in detail for paleofluids. The breccia clasts are firmly cemented by distinct generations of hydrothermal quartz (Fig. 4). The breccias are clast- or matrix-supported depending on the location and lack sedimentary features, strongly suggesting a tectonic origin. Locally, the clasts are so silificified that the pristine features of sedimentary rocks disappear. Thus, a large volume of the rock with clasts widespread within the white quartz matrix becomes the main infilling. There, the silicification products occupy a large volume of the rock with clasts widespread within the white quartz matrix. Two main generations of quartz are distinguished: i) early milky quartz crosscutting only the quartzite clasts or replacing the sediments (Etche $4 \mathrm{C}$ and 5), and ii) quartz cementing clasts and as crosscutting fractures. Locally, it develops geodic euhedral clear quartz (Etche 4A).

At room temperature, fluid inclusions in the quartz cement of the quartzite breccias (Etche 4C, and 5) are generally two-phase (Lw), composed of a vapor phase and a liquid phase (Figure $5 a, b$ ). Some rare inclusions contain a third solid phase (halite crystal). The size of the inclusions in the cataclasite cement is around $12 \mu \mathrm{m}$ and rarely exceeds $20 \mu \mathrm{m}$. In the euhedral quartz crystals (Etche 4A) present in the veins and geodes, fluid inclusions are essentially three-phase (Lw-h), containing a vapor phase, a liquid phase, and a halite crystal (Figure $5 \mathrm{c}, \mathrm{d}$ ). The inclusions in the quartz crystals in veins and geodes have sizes around $20 \mu \mathrm{m}$ and can sometimes reach several tens of microns. The shape of the inclusions is locally irregular but mostly sub-rounded. Fluid inclusions are either located at the growth surface of host minerals or randomly distributed within the cores of quartz crystals (primary fluid inclusions). In the investigated samples, no evidence of secondary inclusions was found. Unlike those in the quartz of quartzite breccias, most fluid inclusions in calcite from the cover 
décollement (calcite vein URD E) are a few tens of micrometers large but are single-phase and could not be studied by microthermometry.

\section{Microthermometry}

Although all quartzite breccia samples contained fluid inclusions, only Etche 5 and Etche 4 displayed numerous fluid inclusions of a suitable size for a microthermometric study (>10 $\mu \mathrm{m})$. Therefore, we focused our study on polished sections Etche 5, and Etche 4C, which correspond to the breccia cement, and Etche $4 \mathrm{~A}$ in which we gathered some automorphic quartz crystal picked from geodes and veins crosscutting the breccias.

The majority of fluid inclusions have eutectic temperatures ranging from $-21.2^{\circ} \mathrm{C}$ to $-23^{\circ} \mathrm{C}$, corresponding to the $\mathrm{H}_{2} \mathrm{O}-\mathrm{NaCl}$ system. However, some fluid inclusions, especially in the sample Etche $4 \mathrm{C}$, showed eutectic temperatures between $-33^{\circ} \mathrm{C}$ and $-35^{\circ} \mathrm{C}$, indicative of systems with additional divalent cation salts $\left(\mathrm{H}_{2} \mathrm{O}-\mathrm{NaCl}-\mathrm{CaCl}_{2}-\mathrm{MgCl}_{2}\right)$.

Most of the $\mathrm{Tm}$ ice is between -12 and $-20^{\circ} \mathrm{C}$, the complete range being -7 to $-25{ }^{\circ} \mathrm{C}$. All fluid inclusions homogenize to the liquid phase. TH ranges from 165 to $278^{\circ} \mathrm{C}$ for sample Etche $4 \mathrm{C}$ and Etche 5 (cement in breccia clasts). Halite bearing fluid inclusions in sample Etche 4A (veins and geodes) and some inclusions from sample Etche 5 display lower TH ranging from 168 to $205^{\circ} \mathrm{C}$ (Fig 6 and 7). Tm halite is mainly observed between 196 and $255^{\circ} \mathrm{C}$ and is around $50-70{ }^{\circ} \mathrm{C}$ higher than $\mathrm{TH}$ (Fig 8).

The salinity of fluid inclusions (Figs. 6, 7) was determined either from ice melting temperatures for liquid-vapor fluid inclusions or from the halite melting temperature for three-phase fluid inclusions at room temperature (Bodnar and Vityk, 1994). Fluid inclusions in the quartz cement (Etche 4C, Etche 5) show a wide range of salinity, with values ranging between 10.4 and $23.1 \mathrm{wt} \% \mathrm{NaCl}$ equiv., with a maximum of measurements around $20 \mathrm{wt} \% \mathrm{NaCl}$ equiv. The rare three phase fluid inclusions found in these samples have salinities of about 33 wt $\% \mathrm{NaCl}$ equiv. By contrast to those in cement, fluid inclusions in quartz from veins and geodes have relatively homogeneous chlorinities. Their salinity values range between 30 and 37 wt\% $\mathrm{NaCl}$ equiv. but with $90 \%$ of values falling around $34 \mathrm{wt} \% \mathrm{NaCl}$ equiv. The $\mathrm{Cl} / \mathrm{Br}$ molar ratios from geodic quartz are 2007 and 2321 . The $\delta^{37} \mathrm{Cl}$ values are -0.15 and $0.16 \%$

\section{Raman spectroscopy}

Raman spectroscopy of the liquid phase of fluid inclusions in both Etche 4 and Etche 5 quartz shows a spectrum differing from a pure water spectrum. This spectrum is characterized by a decrease in intensity around $3200 \mathrm{~cm}^{-1}$, an increase in intensity around $3450 \mathrm{~cm}^{-1}$ and a small shift towards a higher frequency of the maximum intensity of the whole band, indicative of an increase of salt 
concentration in water (Dubessy et al., 2002). This result is consistent with the high salinity values deduced from microthermometry.

Traces of $\mathrm{CH}_{4}, \mathrm{~N}_{2}$ were found in Lw fluid inclusions present in the quartz of the Etche breccias (Fig. 9). $\mathrm{CH}_{4}$ was detected in almost all analysed fluid inclusions and is predominant. Trace amounts of $\mathrm{N}_{2}$ were also detected in most fluid inclusions. In addition to $\mathrm{CH}_{4}$ and $\mathrm{N}_{2}$, part of $\mathrm{Lw}$-h inclusions shows $\mathrm{CO}_{2}$ content ranging from 11 to 25 moles\%.

The liquid phase in fluid inclusions of the URD E calcite, unlike those in Etche quartz, shows a spectrum typical of very low salinity around $1 \mathrm{wt} \% \mathrm{NaCl}$ equiv. ( 0.2 molal).

\section{Discussion}

Brecciation and silicification along the crust-mantle detachment

Evidence of two superimposed episodes of silicification in the Etche samples: Silicified breccia samples consist of Ordovician angular clasts in a siliceous cement, with euhedral geodic quartz and late quartz veins crosscutting both the clasts and the inter-clast siliceous cement. The microthermometry results show that fluid inclusions in these veins and geodic quartz almost all have salinities around $34 \mathrm{wt} \% \mathrm{NaCl}$ equiv. In contrast, those in the inter-clast cement have a wide range of salinity, varying mainly from 10.4 to 23 wt $\% \mathrm{NaCl}$ equiv. (and even up to $32 \mathrm{wt} \% \mathrm{NaCl}$ equiv. considering the rare halite bearing fluid inclusions).

All these differences highlighted between the fluid inclusions in the breccia cement and those in the late veins and geodic quartz lead us to consider two successive stages of circulation of the siliceous fluids along the Urdach crust-mantle detachment: a first circulation resulting in the formation of the inter-clastic cement followed by a second circulation responsible of the quartz veins and geodic quartz. The differences in salinity observed between the two silicification stages can be caused by a progressive shift in the reservoirs involved in the model. First, the wide range of salinity found in the fluid inclusions from the inter-clastic cement may have resulted from the mixing of two types of fluids: a very salty fluid (a brine) and a lower salinity fluid. In contrast, the crystallization of quartz vein and geode infillings result from a single brine of around $34 \mathrm{wt} \% \mathrm{NaCl}$ equiv. (Fig. 10). Such an evolution in salinity would then require the formation of a watertight barrier between the two stages, limiting the participation of the lower-salinity fluid in the process.

Based on the geological context of the Urdach Massif, the modified seawater of the Albian basins appears to be one of the best candidates to represent the main reservoir that delivered fluids in the studied system. Its involvement at a regional scale is confirmed by the serpentinization and carbonation affecting some of the NPZ exhumed mantle bodies, mostly in the western Pyrenees (Lagabrielle et al., 2019a, b). 
Besides seawater, the high salinity observed in the fluid inclusions of the Etche quartzite breccias points to the implication of another reservoir, highly concentrated in salt. The source of salt-rich fluids in the region has been identified as the $1 \mathrm{~km}$ to $2 \mathrm{~km}$ thick evaporite-rich Late Triassic layers (Keuper facies) that were present at the base of the pre-rift sequence of the Chainons Béarnais and the NPZ in general (Canérot et al., 1978; James and Canérot, 1999; Corre et al., 2018; Lagabrielle et al., 2019b). These layers represent weak formations that accommodated the gliding of the pre-rift cover toward the center of the Cretaceous basins where mantle rocks were locally denudated (Lagabrielle et al., 2010, Teixell et al., 2016). The Keuper layers are present in the entire Pyrenean realm through seismic, well and field data in the Bay of Biscay, Aquitaine basin, Basque-Cantabrian belt and the Southern Pyrenees (Biteau et al., 2006; Jammes et al., 2010; Saura et al., 2016; Orti et al., 2017; Lagabrielle et al., 2020). Mechanical crushing of this layer in the presence of fluids would thus probably have released brines which would have then participated in the cementation of the hydraulic breccia.

The first silicification in the Etche samples is probably related to a mixing process between a fluid having salinities lower than $10 \mathrm{wt} \% \mathrm{NaCl}$ equivalent and Triassic brines. The lower salinity fluid could be seawater or connate waters. The most efficient processes to deposit quartz are temperature and pressure drops, as quartz solubility decreases when P or T decrease (Fournier, 1983). Both could have occurred, as the brines are cooler than the less saline fluid, and that pressure could have dropped at each increment of the brecciation event. The formation of the late veins and geodes would be associated only with the Triassic brines. In that case, as no more mixing occurs, the pressure drop linked to the new stages of fracture formation could be the leading cause of quartz deposition. We suppose that the Triassic brines are released during the crushing of the evaporitic levels and associated leaching process by fluids entering the system (primary and secondary brines). Thus, the initiation of the silicification of the tectonic breccias can be viewed as a consequence of the gliding of the pre-rift cover, a process contemporary with crustal thinning of the distal domain of the Iberia margin according to models of the rift evolution in the western Pyrenees (e.g., Jammes et al., 2010, Corre et al., 2016; Teixell et al., 2016). These processes are precursors of the complete denudation of the serpentinized mantle in localized spots of the North Pyrenean Zone, such as the Urdach massif, during the late Albian. The traces of $\mathrm{CH}_{4}, \mathrm{~N}_{2}$, and $\mathrm{CO}_{2}$ detected in the fluid inclusions may be related to various processes, and unfortunately cannot be considered as symptomatic of a unique geodynamical setting. However, the presence of $\mathrm{N}_{2}$ could indicate that these fluids have oxidized ammonium present in clays, micas, or feldspars. $\mathrm{CH}_{4}$ can be released from organic matter-rich clay layers or may also be issued from the serpentinisation of the mantle in the presence of carbon species (Schrenk et al., 2013). 
P-T conditions for fluid circulation: Fluid inclusions in silicified quartzite breccias showed minimum trapping temperatures ranging from 200 to $280^{\circ} \mathrm{C}$ for fluid inclusions in the siliceous cement, and from 155 to $200^{\circ} \mathrm{C}$, with a mode around $170-180^{\circ} \mathrm{C}$ for fluid inclusions in the late vein quartz and geodes. Corresponding isochores are plotted in Fig. 10. The trapping conditions have been bracketed based on several considerations: i) the size of the halite cube, somewhat similar among the studied Lw-h inclusions, indicates that $\mathrm{NaCl}$ was not nucleated before the trapping and that salts are daughter inclusions. $\mathrm{Tm}$ halite, which is higher by $50-70^{\circ} \mathrm{C}$ than $\mathrm{TH}$, can be therefore considered as a minimal trapping temperature: $230-240^{\circ} \mathrm{C}$ (Fig. 8). ii) the NPZ was affected by rather high thermal gradients. Gradients of $40^{\circ} \mathrm{C} / \mathrm{Km}$ to $60^{\circ} \mathrm{C} / \mathrm{Km}$ were used in the P-T diagram (Fig. 10). For the brines $\mathrm{Lw}$-h, the $\mathrm{Tm}$ halite at $230-240^{\circ} \mathrm{C}$ for a TH of $170^{\circ} \mathrm{C}$ constrains the pressure above 1300 bars, which can only be interpreted as lithostatic pressure. Considering isochores and lithostatic gradients, the most probable trapping conditions for the brines Lw-h are: $240-280^{\circ} \mathrm{C}$ and $1300-1800$ bars. The formation of the late vein quartz in the brecciated quartzite along the crust-mantle detachment could have started at a maximum depth of 5 to $6 \mathrm{~km}$ (Fig. 10). For the Lw earlier fluids, their TH is higher than those of Lw-h, yielding to a shift of isochores to higher temperatures. For the Lw fluids, the same approach yields an estimate of $280-320^{\circ} \mathrm{C}$ and $1300-1800$ bars. In the Urdach massif, measurements of graphite crystallinity using Raman spectrometry on carbon-rich grains in marbles from the base of the Mesozoic cover as well as in the Cretaceous flysch show that temperatures in this area never exceeded $300 \pm 20^{\circ} \mathrm{C}\left(285^{\circ} \mathrm{C}\right.$ in the studied zone: Clerc et al., 2015; Corre, 2017). These values are compatible with our results, as well as the low-grade parageneses of HT-LP metamorphism with temperatures generally below $350^{\circ} \mathrm{C}$ in the western part of the northern Pyrenean zone (Clerc et al., 2015). Hart et al (2017) proposed thermal gradients up to $100^{\circ} \mathrm{C}$ in the Pyrenees based on estimated temperatures from U-Th-He method $\left(>180^{\circ} \mathrm{C}\right.$, imprecise temperature range because no higher value is given) and inferred burial depth $(2 \mathrm{~km})$ which is not compatible with other P-T estimates as discussed above.

\section{Fluids in the cover-décollement at Col d'Urdach}

The calcite vein from the thick fault zone forming the cover décollement at the base of the detached pre-rift Mesozoic cover at Col d'Urdach (URD E sample) contains exclusively aqueous fluid inclusions, with low salinity and devoid of traces of gas. Since these fluid inclusions are all single-phase, no minimum trapping temperature could be measured. The absence of a vapor bubble in these inclusions suggests that the fluid was trapped at low temperature $\left(<80-100^{\circ} \mathrm{C}\right)$. The preservation of their monophase feature and their possible metastability suggest that they represent the very final stages of fluid-mantle interactions in the area, when the serpentinized peridotites were exposed to the seafloor. Inclusions also have low salinity, around one third of the salinity of modern seawater. 
Relatively low temperatures that never exceeded $250^{\circ} \mathrm{C}$ are proposed by Lagabrielle et al. (2019a) in the vicinity of the Urdach décollement. These authors suggest that the Col d'Urdach exposes the shallowest portion of the décollement along which the pre-rift cover was progressively transported and tectonically emplaced on top of exhumed mantle rocks forming the seafloor of the Albian basin. Our data suggest that during the last stages of its evolution, this shallow portion of the décollement has been characterized by the circulation of low-temperature fluids corresponding to seawater lacking evidence of interactions with deepest parts of the system including continental basement and mantle rocks.

\section{A conceptual model of fluid circulation in the Iberia distal paleo-margin}

We propose a conceptual reconstruction of fluid circulations along the crust-mantle detachment during the exhumation of the mantle Urdach body. This reconstruction is based on previous models deciphering the thinning modes of the distal margin of the northern Iberia plate (Corre et al., 2016; Teixell et al., 2016; Asti et al., 2019; Lagabrielle et al., 2019 a, b) (Fig. 11). According to such models, thin tectonic lenses of continental crustal basement were exhumed together with the mantle during the Late Albian. As evidenced by Asti et al. (2019), these lenses were first deformed in a dominant ductile mode along the detachment, then underwent a brittle deformation after crossing the ductile/brittle transition, forming tectonic breccias as depicted in figure 12. Geologically based thermo-mechanical models reproduce the behaviour of the overall Cretaceous Pyrenean rift system, including décollement of the pre-rift cover, detachment along the mantle/crust boundary and dominant ductile thinning mode of the continental crust (Duretz et al., 2019).

Thus, following most of the previous models applying to the Urdach area, we assume that stretching of the distal Iberia margin was accommodated by homogeneous ductile thinning of the Paleozoic basement and by major displacement along the crust-mantle detachment (Fig. 11). Crustal hyperthinning also coincided with the sliding of the Mesozoic cover towards the center of the rift basin. Sliding occurred along the cover décollement corresponding to the low-strength Triassic clays and evaporites (Fig. 11). In their study of the Chaînons Béarnais, Incerpi et al. (2020) also point to fluid-rock interactions during the late stage of hyperextension. They show that dolomitic marbles and mylonites formed during the Cenomanian, implying evaporitic fluids and strong Mg-metasomatism. Figure 12 depicts our proposed conceptual reconstruction of the fluid pathways along the crustmantle detachement at the Urdach body.

1. First, our results suggest that Triassic primary brines mixed with lower salinity fluids (Fig. 12) and contributed to the silicification of the hyper-thinned remnants of the Paleozoic basement still welded on the exhumed mantle. 
In a first stage, the mixture of these primary brines with more dilute fluids (fluid B in Fig. 12) such as formation waters or seawater, resulted in the genesis of the primary siliceous cement in Ordovician quartzite tectonic breccias, at temperatures of about $280-320^{\circ} \mathrm{C}$ (Fig. 12 stage 1, Late Albian). The more dilute fluids are characterized by slightly higher temperatures due to the mantellic thermal anomaly. The subsequent cooling of the hottest end-member during mixing is probably the main factor controlling the quartz precipitation. Fluid pressure higher than the local stress field caused the brecciation of the host-rock. The pressure drop yielded consequently to the intense precipitation of quartz and silicification of the percolation pipes.

Following this earliest silicification event the tectonic breccias were denudated in response to mantle exhumation and were exposed to the seafloor. Once exposed, both the Ordovician quartzite tectonic breccias and the ultramafic basement were reworked by sedimentary processes to form the Urdach breccia (Debroas et al., 2010). Formation of the Urdach breccia was synchronous with the deposition of the Late Albian flysch deposits, which are in places interfingered with breccia layers.

2. In a second stage, during the Cenomanian, the flysch deposits became thicker and progressively formed a watertight barrier that prevented seawater from continuous downward penetration. At this stage, only the Triassic brines were able to circulate along the crust-mantle detachment at Urdach. As the exhumation process continued, the tectonic breccias (already silicified) were affected by fractures in which flowed Triassic brines that precipitated quartz at temperatures of approximately $260 \pm 20^{\circ} \mathrm{C}$ (Fig. 12 step 2).

\section{New evidence for an extreme metasomatic Cretaceous event involving Triassic brines}

Finally, our results indicate that the exhumation of the mantle serpentinized peridotites has been accompanied by a downward (seawater, Triassic brines) and upward circulation (convecting fluids) of large amounts of fluids (Fig. 11). As the mantle was exhumed near to the seafloor, the mantle was crossed by significant amounts of seawater infiltrating downward and leading to the genesis of ophicalcites (Fig. 11). The role of mantle metasomatism on the formation of primary brines is however still difficult to decipher, as discussed by Quesnel et al. (2019) in the Trimouns deposit example. Synchronously, deformation along the basement/sedimentary cover favoured primary brines expulsion from the Triassic material. Corre et al. (2018) described similar brines that circulated at the base of the Mesozoic cover, in contact with mantle rocks at the nearby Saraille mantle body (Fig. 2). In both the Urdach and Saraillé massifs, the first origin of brine is likely the squeezing of the Triassic evaporites. At Saraillé, a magmatic origin, as suggested by Salardon et al. (2016) for the brines is rather unlikely as there is no evidence of massive magmatic inputs at that time. The Urdach brine end-member has almost the same chlorinity and trapping temperatures as those identified at Trimouns (Boiron et al., 2007, Quesnel et al., 2019) (Fig. 11). At Trimouns, the primary origin of these 
evaporitic brines was evidenced by the low $\mathrm{Cl} / \mathrm{Br}$ ratio and the chlorinity close to those of primary brines having passed halite saturation, and by the range of $\delta^{37} \mathrm{Cl}$ isotopes typical of evaporated seawater. The primary brines, as shown by Quesnel et al. (2019), are rich in Mg and therefore have favoured the formation of Mg-rich minerals (dolomite after limestones, newly formed talc at the expense of micaschists) along a hectometre thick shear zone separating migmatitic gneisses from Paleozoic sediments. Such Triassic brines were also involved in other intense water-rock interactions yielding to metasomatic facies (albitites, Boulvais et al., 2007; dolomitized limestones, Lagabrielle et al., 2019). The silicification predominates at Urdach probably because lithologies are mostly quartzites and does not favour the formation of other minerals. Secondary brines issued from halite dissolution are identified at Urdach during the late stage (geodic quartz) as indicated by the rather high $\mathrm{Cl} / \mathrm{Br}$ ratio around 2000, and the compatibility of $\delta^{37} \mathrm{Cl}$ values $(-0.15$ and $-0.16 \%)$ with an evaporitic origin of the chlorine. Formation of these secondary brines is probably favoured by lateral fluid circulation but not by direct downward marine water circulation.

The role of the Late Triassic evaporites as a source of hot brines and related metasomatism is therefore well documented during the Cretaceous times from these two examples. Such a model can be extended along strike to other areas of the NPZ hosting mantle bodies as well as along the IberiaEurasia plate boundary (Lagabrielle et al., 2020). A recent thermal model of the evolution of the NPZ during the crustal hyper-extension in the Cretaceous emphasizes the role of the Triassic décollement level as well as additional salt-controlled deformations, including diapirism (Saspiturry et al., 2020). All models collectively point to the role of the Triassic sediments in maintaining a thermal anomaly in the center of the rift (Duretz et al., 2019; Lagabrielle et al., 2020 and references therein) because the Triassic low-strength layer favoured the sliding of the pre-rift cover toward the basin axis. The major consequences of this central basin thermal anomaly are three fold: (i) the ductile deformation of the thinned continental crust beneath the detached pre-rift units avoiding the initiation of brittle faulting (smooth-slopes basins geometry), (ii) the development of HT-LP conditions in the pre-rift sediments and at the base of the syn-rift flysch levels corresponding to the so-called Pyrenean thermal metamorphism and iii) the expulsion of a large volume of fluids from the décollement level coeval with these deformational events.

\section{Conclusion}

The Urdach massif displays numerous pieces of evidence of fluid-rock interactions along two major Cretaceous discontinuities active during the Pyrenean rifting event. These are calcite-serpentinechlorite layered fault rocks located along the cover décollement and abundant silicification of 
Paleozoic quartzite tectonic breccias along the crust-mantle detachment. The main conclusions of our study of fluid inclusions found in the fault material are as follows:

- Several fluid types have circulated in this context: i) Brines issued from the squeezing and deformation of Late Triassic (Keuper) evaporites and their leaching by fluids entering the decollement, ii) Fluids resulting from the dilution of brines by less saline waters which could be either fresh waters issued from squeezing of shales or modified seawater. These fluids are only registered during the early stage of pervasive silicification by the dilution trend of the brines. The mixing process is well documented by the rather large of salinity from 10 to $38 \mathrm{wt} \% \mathrm{NaCl}$ equivalent. The hotter lesssaline end-member could indicate a more in-depth circulation loop and are probably in thermal disequilibrium when reaching the host formations. Brines from Trias are close to their production zone and may represent the temperature of the formations at that time, around $240-280^{\circ} \mathrm{C}$, at pressures from 1300 to 1800 bars, e.g., at a depth estimated around $6 \pm 1 \mathrm{~km}$.

- The brecciation could have been produced by the fluid pressure of the ascending fluids, higher than that related to the local stress field. The pressure drop yielded consequently to the intense precipitation of quartz and silicification of the percolation pipes. Brines become the dominant fluid circulating at the end of the process. Thus, the silicification event has been actively controlled by the deposit of flysch layers, which have progressively constituted a barrier limiting the involvement of less saline waters in the system significantly. Finally, the Triassic brines were the only fluids able to circulate along the crust-mantle detachment at later stages.

- This study provides renewed evidence of the critical influence of Triassic evaporites in the mineralogical and rheological transformations that occurred during the Pyrenean Cretaceous rifting event. These transformations were mostly controlled by the release and the migration of significant volumes of brines during the stretching and squeezing of the Triassic evaporites and clays.

\section{Acknowledgements}

This work was made possible through grants from the Program "Référentiel Géologique de la France" (RGF) of the French Bureau de Recherches Géologiques et Minières (BRGM) to co-authors at University of Rennes. Thierry Baudin, head of the RGF program, is acknowledged for his support during this study. Philippe Boulvais (Geosciences Rennes) is thanked for having facilitated the link between Nancy and Rennes through Jehiel Nteme's master degree. Thanks are due to Serge Fourcade and Riccardo Asti for fruitful discussions around field data. Pierre Agrinier and Gérard Bardoux are thanked for their help during the analysis of $\mathrm{Br}, \mathrm{Cl}$ concentrations and $\mathrm{Cl}$ isotopes. JeanEric Rose is acknowledged for his assistance in the field at Col d'Etche. Margaret Odlum and Nicolò 
Incerpi are warmly thanked for their constructive and pertinent comments which greatly helped to improve the manuscript. Kathryn Cutts is acknowledged for her editorial handling.

\section{Authors Contributions}

Jehiel Nteme (JN), Yves Lagabrielle (YL), Marie-Christine Boiron (MCB) Michel Cathelineau (MC) and Benoit Quesnel (BQ) made the field work and collected the samples. YL was involved in the funding by the RGF, BRGM program. During his master degree, JN performed the fluid inclusion study under the supervision of $\mathrm{MCB} . \mathrm{BQ}$ acquired the $\mathrm{Cl}, \mathrm{Br}$ data. Interpretation of the data and writing of the manuscript was done by all the authors. 


\section{REFERENCES}

Agrinier, P., Mével, C. and Girardeau, J. 1988. Hydrothermal alteration of the peridotites cored at the ocean/continent boundary of the Iberian margin: petrologic and stable isotope evidence. In: Boillot G, Winterer EL, et al., eds. Proceedings of the Ocean Drilling Program, Scientific Results, College Station, TX (Ocean Drilling Program) 103: 225-234. https://doiorg.insu.bib.cnrs.fr/10.2973/odp.proc.sr.103.136.1988.

Alt, J. C. and Shanks, W. C. 2003. Serpentinization of abyssal peridotites from the MARK area, MidAtlantic Ridge: sulfur geochemistry and reaction modeling. Geochimica Cosmochimica Acta, 67, 641-653.

Asti, R., Lagabrielle, Y., Fourcade, S., Corre, B. and Monié, P. 2019. How do continents deform during mantle exhumation? Insights from the northern Iberia inverted paleo-passive margin, western Pyrenees (France). Tectonics, 38, 1666-1693. DOI: 10.1029/2018TC005428.

Biteau, J. J., Le Marrec, A., Le Vot, M. and Masset, J.M. 2006. The Aquitaine Basin. Petroleum Geoscience, 12(3), 247-273. DOI: 10.1144/1354-079305-674.

Bodnar, R. J. and Vityk, M.O. 1994. Interpretation of microthermometric data for $\mathrm{H}_{2} \mathrm{O}-\mathrm{NaCl}$ fluid inclusions. Fluid inclusions in Minerals, Methods and Applications, B. De Vivo and M. L. Frezzotti, eds., pub. by Virginia Tech, Blacksburg, VA, p. 117-130.

Boiron, M.C., Cathelineau, M., Dubessy, J., Fabre, C., Boulvais, P. and Banks, D.A. 2007. Na-Ca-Mg rich brines and talc formation in the giant talc deposit of Trimouns (Pyrenees): fluid inclusion chemistry and stable isotope study. European Current Research on Fluid Inclusion, Bern, p. 90 .

Boschi, C., Bonatti, E., Ligi, M., Brunelli, D., Cipriani, A., Dallai, L., D'Orazio, M., Früh-Green, G.L., Tonarini, S., Barnes, J.D. and Bedini, R.M. 2013. Serpentinization of mantle peridotites along an uplifted lithospheric section, Mid Atlantic Ridge at $11^{\circ} \mathrm{N}$. Lithos, 178, 3-23, https://doi.org/10.1016/j.lithos.2013.06.003.

Boulvais, P., de Parseval, P., D'Hulst, A. and Paris, P. 2006. Carbonate alteration associated with talcchlorite mineralization in the eastern Pyrenees, with emphasis on the St. Barthelemy Massif. Mineralogy and Petrology, 88, 499-526.

Boulvais, P., Ruffet, G., Cornichet, J. and Mermet, M. 2007. Cretaceous albitization and dequartzification of Hercynian peraluminous granite in the Salvezines Massif (French Pyrénées). Lithos, 93, 89-106. 
Canérot, J. and Delavaux, F. 1986. Tectonic and sedimentation on the north Iberian margin, Chainons Béarnais south Pyrenean zone (Pyrenees basco-béarnaises) - New data about the signification of the Iherzolites in the Saraillé area. Comptes Rendu Académie des Sciences, 302, 951-956.

Canérot, J., Peybernes, B. and Cizsak, R. 1978. Présence d'une marge méridionale à l'emplacement des Chaînons Béarnais (Pyrénées basco-béarnaises). Bulletin de la Société Géologique de France, $7(20), 673-676$.

Canérot, J. 2017. The pull apart-type Tardets-Mauléon Basin, a key to understand the formation of the Pyrenees. Bulletin de la Société Géologique de France, 188, 35. DOI: $10.1051 / \mathrm{bsgf} / 2017198$

Casteras, M., Canérot, J., Paris, J-P., Tisin, D., Azambre, B. and Alimen, H. 1970. Carte géol. France (1/50 000), feuille Oloron-Sainte-Marie (1051). Orléans: BRGM.

Choukroune, P., ECORS team, 1989. The Ecors deep seismic profile reflection data and the overall structure of an orogenic belt. Tectonics, 8, 23-39.

Choukroune, P. and Mattauer, M. 1978. Tectonique des plaques et Pyrénées ; sur le fonctionnement de la faille transformante nord-pyrénéenne; comparaisons avec des modèles actuels. Bulletin de la Société Géologique de France, 5, 689-700.

Clerc, C. and Lagabrielle, Y. 2014. Thermal control on the modes of crustal thinning leading to mantle exhumation: Insights from the Cretaceous Pyrenean hot paleomargins. Tectonics, 33, 1340-1359.

Clerc, C., Boulvais, P., Lagabrielle, Y. and de Saint Blanquat, M. 2013. Ophicalcites from the northern Pyrenean Belt: a field, petrographic and stable isotope study. International Journal Earth Sciences, 1-23.

Clerc, C., Lahfid, A., Monié, P., Lagabrielle, Y., Chopin, C., Poujol, M., Boulvais, P., Ringenbach, J.-C., Masini, E. and de St Blanquat, M. 2015. High-temperature metamorphism during extreme thinning of the continental crust: a reappraisal of the North Pyrenean passive paleomargin. Solid Earth, 6, 643-668.

Corre, B. 2017. La bordure nord de la plaque ibérique à l'Albo-Cénomanien. Architecture d'une marge passive de type ductile (Chaînons Béarnais, Pyrénées Occidentales). Unpublished thesis, Univ. Rennes 1, $300 \mathrm{p}$. 
Corre, B., Lagabrielle, Y., Labaume, P., Fourcade, S., Clerc, C. and Ballèvre, M. 2016. Deformation associated with mantle exhumation in a distal, hot passive margin environment: new constraints from the Saraillé Massif (Chaînons, North-Pyrenean Zone). Comptes Rendus Géosciences, 348, 279-289.

Corre, B., Boulvais, P., Boiron, M.C., Lagabrielle, Y., Marasi, L. and Clerc, C. 2018. Fluid circulations in response to mantle exhumation at the passive margin setting in the north Pyrenean zone, France. Mineralogy and Petrology, 97, 109-142. DOI: 10.1007/s00710-018-0559-x.

Dauteuil, O. and Ricou, L.E. 1989. Une circulation de fluides de haute température à l'origine du métamorphisme crétacé' nord-Pyrénéen. Geodynamica Acta, 3, 237-250.

Debroas, E.J., Canérot, J. and Bilotte, M. 2010. Les Brèches d'Urdach, témoins de l'exhumation du manteau pyrénéen dans un escarpement de faille Vraconnien-Cénomanien inférieur (zone nord-pyrénéenne, Pyrénées-Atlantiques, France). Géologie de la France, 2, 53-63.

Deramond, J., Souquet, P., Fondecave-Wallez, M.J. and Spetch, M. 1993. Relationships between thrust tectonics and sequence stratigraphy surfaces in foredeeps: Model and example from the Pyrenees (Cretaceous-Eocene, France, Spain), in Tectonics and Seismic Sequence Stratigraphy, edited by G.D. Williams and A. Dobb, Geological Society, London, Special Publications, 71, 193-219.

Dubessy J., Lhomme T., Boiron M.C. and Rull. F. 2002, Determination of chlorinity in aqueous fluids using Raman spectroscopy of the stretching band of water at room temperature: application to fluid inclusions. Applied Spectroscopy, 56, 99-106.

Duretz, T., Asti, R., Lagabrielle, Y., Brun, J.P., Jourdon, A., Clerc, C. and Corre, B. 2019. Numerical modelling of syn-rift salt tectonics and mantle exhumation in the Cretaceous Pyrenean Rift. Basin Research, doi.org/10.1111/bre.12389

Espurt, N., Angrand, P., Teixell, A., Labaume, P., Ford, M., de Saint Blanquat, M., and Chevrot, S. 2019. Crustal-scale balanced cross-section and restaurations of the Central Pyrenean belt (Nest- Cinca transect): superimposed orogenesis and Pyrenean rift system evolution.

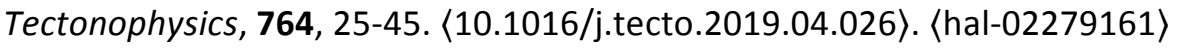

Fallourd, S., M. Poujol, P. Boulvais, J.-L. Paquette, M. de Saint Blanquat, and P. Rémy. 2014. « In Situ LA-ICP-MS U-Pb Titanite Dating of Na-Ca Metasomatism in Orogenic Belts: The North Pyrenean Example ». Int J Earth Sci (Geol Rundsch) (2014) 103, 667-682, doi.org/10.1007/s00531-013-0978-1 
Fournier, R.O. 1983. A method of calculating quartz solubilities in aqueous sodium chloride solutions, Geochimica Cosmochimica Acta, 47, 579-586.

Glennie, K.W., Boeuf, M.G.A., Hughes-Clarke, M.W., Moody-Stuart, M., Pilaar, W.F.H. and Reinhardt, B.M. 1974. Geology of the Oman Mountains: Koninklijk, Nederlands Geologisch Mijnbouwkundig Genootschap. Verhandelingen, 31, 423 p.

Golberg, J.M. and Leyreloup, A.F. 1990. High temperature-low pressure Cretaceous metamorphism related to crustal thinning (Eastern North Pyrenean Zone, France). Contributions to Mineralogy and Petrology, 104, 194-207. DOI: 10.1007/BF00306443.

Gong, Z., Langereis, C.G. and Mullender, T.A.T. 2008. The rotation of Iberia during the Aptian and the opening of the Bay of Biscay. Earth and Planetary Science Letters, 273, 80-93.

Halls, C. and Zhao, R. 1995. Listvenite and related rocks: perspectives on terminology and mineralogy with reference to an occurrence at Cregganbaun, Co. Mayo, Republic of Ireland. Mineralium Deposita, 30, 303-313.

Harlov, D.E. and Austrheim, H. 2013. Metasomatism and the chemical transformation of rock: rockmineral-fluid interaction in terrestrial and extraterrestrial environments. In Metasomatism and the Chemical Transformation of Rock. Springer, Berlin, Heidelberg.

Hart, N.R., Stockli, D.F., Lavier, L.L. and Hayman, N.W. 2017. Thermal evolution of a hyperextended rift basin, Mauléon Basin, western Pyrenees. Tectonics, 36, 1103-1128.

Incerpi, N., Martire, L., Manatschal, G., Bernasconi, S.M., Gerdes, A., Czuppon, G., Palcsu, L., Karner, G.D., Johnson, C.A. and Figuero, P.H. 2019. Hydrothermal fluid flow associated to the extensional evolution of the Adriatic rifted margin: Insights from the pre- to post-rift sedimentary sequence (SE Switzerland, N Italy). Basin Research, 32, 91-115.

Incerpi, N., Manatschal, G., Martire, L., Bernasconi, S.M., Gerdes, A. and Bertok, C. 2020. Characteristics and timing of hydrothermal fluid circulation in the fossil Pyrenean hyperextended rift system: new constraints from the Chaînons Béarnais (W Pyrenees). International Journal of Earth Sciences, doi.org/10.1007/s00531-020-01852-6.

James, V. and Canérot, J. 1999. Diapirisme et structuration post-triasique des Pyrénées occidentales et de l'Aquitaine méridionale (France). Eclogae Geologicae Helvetiae, 92, 63-72.

Jammes, S., Manatschal, G., Lavier, L. and Masini, E. 2009. Tectonosedimentary evolution related to extreme crustal thinning ahead of a propagating ocean: example of the western Pyrenees. Tectonics, 28, TC4012, doi:10.1029/2008TC002406 
Jammes, S., Manatschal, G. and Lavier, L. 2010. Interaction between prerift salt and detachment faulting in hyperextended rift systems: The example of the Parentis and Mauléon basins (Bay of Biscay and western Pyrenees). AAPG Bulletin, 94, 957-975.

Karson, J. A., Fru“h-Green, G. L., Kelley, D. S., Williams, E. A., Yoerger, D. R. and Jakuba, M. 2006. Detachment shear zone of the Atlantis Massif core complex, Mid-Atlantic Ridge, $30^{\circ}$, Geochemistry Geophysics Geosystems, 7, Q06016, doi:10.1029/2005GC001109.

Lafay, R., Baumgartner, P.L., Schwartz, S., Picazo, S., Montes-Hernandez, G. and Vennemann T., 2017. Petrologic and stable isotopic studies of a fossil hydrothermal system in ultramafic environment (Chenaillet ophicalcites, Western Alps, France): processes of carbonate cementation. Lithos, 294-295, 319-338. DOI: 10.1016/j.lithos.2017.10.006.

Lagabrielle, Y. and Bodinier, J. L. 2008. Submarine reworking of exhumed subcontinental mantle rocks: field evidence from the Lherz peridotites, French Pyrenees. Terra Nova, 20, 11-21.

Lagabrielle, Y., Labaume, P. and de Saint Blanquat, M. 2010. Mantle exhumation, crustal denudation, and gravity tectonics during Cretaceous rifting in the Pyrenean realm (SW Europe): Insights from the geological setting of the Iherzolite bodies. Tectonics, 29. doi.org/10.1029/2009TC002588

Lagabrielle, Y., Asti, R., Fourcade, S., Corre, B., Poujol, M., Uzel, J., Labaume, P., Clerc, C., Lafay, R., Picazo, S. and Maury, R. 2019a. Mantle exhumation at magma-poor passive continental margins. Part I. 3D architecture and metasomatic evolution of a fossil exhumed mantle domain (Urdach Iherzolite, north-western Pyrenees, France). Bulletin de la Société Géologique de France, 190, 8 . doi.org/10.1051/bsgf/2019007

Lagabrielle, Y., Asti, R., Fourcade, S., Corre, B., Uzel, J., Labaume, P., Uzel, J., Clerc, C., Lafay, R. and Picazo S. 2019b. Mantle exhumation at magma-poor passive continental margins. Part II. Tectonic and metasomatic evolution of large-displacement detachment faults preserved in a fossil distal margin domain (Saraillé Iherzolites, north-western Pyrenees, France). Bulletin de la Société Géologique de France, 190,14. doi.org/10.1051/bsgf/2019013

Lagabrielle,Y., Asti, R., Duretz, T., Clerc, C., Fourcade, S., Teixell, A., Labaume, P., Corre, B. and Saspiturry, N. 2020. A review of cretaceous smooth-slopes extensional basins along the Iberia-Eurasia plate boundary: How pre-rift salt controls the modes of continental rifting and mantle exhumation Earth Science Reviews, 201, 103071. doi.org/10.1016/j.earscirev.2019.103071 
Le Pichon, X., Bonnin, J. and Sibuet, J.C.1970. La faille nord-pyrénéenne: faille transformante liée à l'ouverture du golfe de Gascogne. Comptes Rendus de l'Académie des Sciences, 271, 19411944.

Ludwig, K.A., Kelley, D.S., Butterfield, D.A., Nelson, B.K. and Früh-Green, G. 2006. Formation and evolution of carbonate chimneys at the Lost City Hydrothermal Field. Geochimica Cosmochimica Acta, 70, 3625-3645.

Mével, C. 2003. Serpentinization of abyssal peridotites at mid-ocean ridges. Comptes Rendus Geosciences, 335, 825-852.

Moine, B., Fortune, J.P., Moreau, P. and Viguier, F. 1989. Comparative mineralogy, geochemistry, and conditions of formation of two metasomatic talc and chlorite deposits; Trimouns (Pyrenees, France) and Rabenwald (Eastern Alps, Austria). Economic Geology, 84, 13981416 .

Muñoz, J.A. 1992. Evolution of a continental collision belt: ECORS-Pyrenees crustal balanced crosssection. In: McClay KR, ed. Thrust tectonics. London, UK: Chapman and Hall, pp. 235-246.

Olivet, J.L. 1996. La cinématique de la plaque ibérique. Bulletin des Centres de Recherche Exploration Production Elf Aquitaine, 20, 131-195.

Orti, F., Perez-Lopez, A. and Salvany, J.M. 2017. Triassic evaporites of Iberia: Sedimentological and palaeogeographical implications for the western Neotethys Evolution during the Middle Triassic-Earliest Jurassic. Palaeogeography, Palaeoclimatology, Palaeoecology, 471, 157180

Picazo, S., Cannat, M., Delacour, A., Escartín, J., Rouméjon, S., and Silantyev, S. 2012. Deformation associated with the denudation of mantle-derived rocks at the Mid-Atlantic Ridge $13^{\circ}-15^{\circ}$ $\mathrm{N}$ : The role of magmatic injections and hydrothermal alteration. Geochemistry Geophysics Geosystems, 13.

Pinto, V. H., Manatschal, G., Karpoff, A. M., and Viana, A. 2015. Tracing mantle-reacted fluids in magma-poor rifted margins: The example of Alpine Tethyan rifted margins. Geochemistry Geophysics Geosystems, 16, 3271-3308.

Plissart, G., Féménias, O., Mãruntiu, M., Diot, H. and Demaiffe, D. 2009. Mineralogy and geothermometry of gabbro-derived listvenites in the Tisovita-luti ophiolite, Southwestern Romania. The Canadian Mineralogist, 47, 81-105. 
Poujol, M., Boulvais, P., Kosler, J. 2010. Regional-scale Cretaceous albitization in the Pyrenees: evidence from in situ $\mathrm{U}-\mathrm{Th}-\mathrm{Pb}$ dating of monazite, titanite and zircon. Journal of the Geological Society, 167, 751-767. doi.org/10.1144/0016-76492009-144

Quesnel, B., Boiron, M.C., Cathelineau, M., Truche, L., Rigaudier, T., Bardoux, G., Agrinier, P., de Saint Blanquat, M., Masini, E. and Gaucher, E.C. 2019, Nature and origin of mineralizing fluids in hyper-extensional systems, the case of Cretaceous Mg-metasomatism in the Pyrenees. Geofluids, doi.org/10.1155/2019/7213050

Roure, F., Choukroune, P. 1998. Contribution of the ECORS seismic data to the Pyrenean geology: crustal architecture and geodynamic evolution of the Pyrenees. Mémoires de la Société géologique de France, 173, 37-52

Roux, J.C. 1983. Recherches stratigraphiques et sédimentologiques sur les flyschs crétacés pyrénéens au sud d'Oloron (Pyrénées-Atlantiques). Thèse $3^{\text {ème }}$ Cycle, Toulouse, 229 p.

Salardon, R., Carpentier, C., Bellahsen, N., Pironon, J. and France-Lanord, C. 2016. Interactions between tectonics and fluid circulations in an inverted hyper-extended basin: Example of mesozoic carbonate rocks of the western North Pyrenean Zone (Chaînons Béarnais, France). Marine and Petroleum Geology, doi: 10.1016/j.marpetgeo.2016.11.018.

Saspiturry, N., Lahfid, A., Baudin, T., Guillou-Frottier, L., Razin, P., Issautier B., Le Bayon, B., Serrano, O., Lagabrielle, Y. and Corre, B. 2020. Paleogeothermal gradients across an inverted hyperextended rift system: Example of the Mauléon fossil rift (Western Pyrenees). Tectonics, doi: 10.17632/47kgv7r9wm.3.

Saura, E., Oró, L.A. i, Teixell, A. and Vergés, J. 2016. Rising and falling diapirs, shifting depocenters, and flap overturning in the Cretaceous Sopeira and Sant Gervàs subbasins (Ribagorça Basin, southern Pyrenees). Tectonics, 35, 638-662. doi.org/10.1002/2015TC004001

Schärer, U., de Parseval, P., Polvé, M. and de Saint Blanquat, M. 1999. Formation of the Trimouns talc-chlorite deposit (Pyrenees) from persistent hydrothermal activity between 112 and 97 Ma. Terra Nova, 11, 30-37.

Schrenk, M.O., Brazelton, W.J., and Lang, S.Q. 2013. Serpentinization, carbon, and deep life. Reviews in Mineralogy and Geochemistry, 75, 575-606.

Souquet P., Debroas E.-J., Boirie J.-M., Pons Ph., Fixari G., Dol J., Thieuloy J.-P., Bonnemaison M., Manivit H. and Peybernès, B. 1985. Le groupe du Flysch noir (albo-cénomanien) dans les 
Pyrénées. Bulletin des Centres de Recherche Exploration Production Elf Aquitaine, 9, 183252.

Teixell, A., 1998. Crustal structure and orogenic material budget in the west central Pyrenees. Tectonics, 17, 395-406.Teixell, A., Labaume, P. and Lagabrielle, Y. 2016. The crustal evolution of the west-central Pyrenees revisited: inferences from a new kinematic scenario. Comptes Rendus Geosciences, 348, 257- 267. doi: 10.1016/j.crte.2015.10.010.

Teixell A, Labaume P, Ayarza P, Espurt N, de Saint Blanquat M and Lagabrielle Y. 2018. The presentday and past crustal structure of the Pyrenean-Cantabrian belt: a review and new interpretations from recent concepts and data. Tectonophysics, 724-725, 146-170 DOI: 10.1016/j.tecto.2018.01.009.

Vacherat, A., Mouthereau, F., Pik, R., Bellahsen, N., Gautheron, C., Bernet, M., Daudet, M., Balansa, J., Tibari, B., Pinna Jamme, R. and Radal, J. 2016. Rift-to-collision transition recorded by tectono-thermal evolution of the northern Pyrenees: Tectonics, 35, doi: 10.1002/2015TC004016.

Zhang, Y.G. and Frantz, J.D. 1987. Determination of the homogeneization temperatures and densities of supercritical fluids in the system $\mathrm{NaCl}-\mathrm{KCl}-\mathrm{CaCl}_{2}-\mathrm{H}_{2} \mathrm{O}$ using synthetic fluid inclusions. Chemical Geology, 64, 335- 350. 
Figure captions

Fig 1. Structural map of the Pyrenees with the location of the North Pyrenean and South Pyrenean Zones and the Axial Zone. NPFT: North-Pyrenean Frontal Thrust, NPF: North-Pyrenean Fault, SPFT: South Pyrenean Frontal Thrust. The area of figure 2 is indicated.

Fig 2. Geological map of the western portion of the Chaînons Béarnais range (modified from Casteras et al., 1970 by Corre, 2017). The area of figure 3 is indicated.

Fig 3. Geological map and a simplified geological section of the Urdach Massif (modified from Lagabrielle et al., 2019a). The main faults active during the Cretaceous Pyrenean rifting are shown (crust-mantle detachment and cover décollement) as well as the location of the samples collected for this study.

Fig 4. Field and sample photographs from the two studied sites. Quartz cemented breccia at Mer de Her and Col d'Etche (a to d). a: quartz cemented breccia, b: quartz cement and quartz veinlets in the breccia c: silicified clasts, and quartz cements, d: late infillings of geodes by euhedral quartz crystals. Serpentinite-calcite fault rock of the Urdach cover décollement (e to g). e : view of the fault contact close to the Col d'Urdach, f: interpretation of a central portion of the décollement, g: close up of sample URD E.

Fig 5. Fluid inclusions morphology. a-b: Two-phases (liquid, vapor) fluid inclusion (Lw) in cataclasite cement sample (Etche 5), c-d: Three-phases (liquid, vapor, halite crystal) fluid inclusion (Lw-h) in geodic quartz sample (Etche $4 \mathrm{~A})$.

Fig 6. Microthermometric data for fluid inclusions of Etche quartz cemented breccia and geodic quartz. A) Histogram of salinities; B) Histogram of homogenization temperatures.

Fig 7. Salinity versus homogenization temperature diagram, with an indication of the seawater salinity. The domain of salinity and homogenization temperature for fluids from the Trimouns talc deposit is represented as a grey box (Boiron et al., 2007; Quesnel et al., 2019). Two additional data points are reported; they correspond to Fl studied in quartz and dolomite from Sarailllé (Corre et al., 2018). 
Fig 8: Homogenization temperature versus melting temperature of halite for three-phase fluid inclusions (Lw-h) from geodic quartz (sample Etche 4A).

Fig 9. Ternary diagram of volatile phases (moles \%) in fluid inclusions.

Fig 10. Pressure-Temperature diagram with isochores and trapping domains for studied inclusions. Red field: Lw-h Fl from geodic quartz (sample Etche 4A), blue field; Lw Fl from breccia cement (samples Etche 4C and Etche 5). Geothermal gradients (lithostatic and hydrostatic) are indicated. The depth is estimated considering lithostatic pressure conditions. Minimal pressure-temperature conditions of trapping are estimated by intersecting the mode of $\mathrm{Tm}$ halite and isochores. Graphite Raman geothermometer data from Corre et al., (2016) are reported for the same location (north of Urdach massif).

Fig 11. Reconstruction of the northern Iberia margin at the end of the Cretaceous Pyrenean rifting event after models of Lagabrielle et al. $(2019 a, b)$ for the Urdach and nearby Saraille mantle bodies. The margin includes two portions: the necking domain and the exhumed mantle domain. The subcontinental mantle has been exhumed and is partially denudated at the foot of the hyperthinned continental crust where it may suffer both massive serpentinization and local carbonation (either static or dynamic, depending on the timing of fluid circulation due to extensional tectonics). The portion of the distal margin shown in figure 12 is indicated.

Fig. 12: Conceptual model of fluid circulation associated with the denudation of the Urdach mantle body during the Late Albian and the Cenomanian at the foot of the northern Iberia continental margin (see location in Fig. 11). Two steps are shown according to the results of our study of the Mer de Her and Etche samples. Step 1: Late Albian: formation of a siliceous cement occurs in breccias formed by overpressure fracturing and brittle deformation along the shallow part of the crust-mantle detachment. Both fluids A (Triassic brines) and B (recharging fluids) are involved. Continuous input of recharging fluid $B$ is possible due to the presence of a very thin blanket of sediments deposited on the denudated mantle. Step 2: formation of veins intersecting the cemented cataclasites. Sedimentary reworking of the silicified cataclasites occurs during the exhumation of the mantle and associated Paleozoic rocks forming the sedimentary Urdach breccia. Due to the deposition of a thick flysch unit of Cenomanian age, recharging fluids B cannot enter the convecting system anymore. Triassic brines, well recorded in the secondary veins of sample Etche $4 \mathrm{~A}$, become predominant. Isotherms are not traced because of weak constraints. Scale is approximative. 


\section{Table Captions}

Table 1: Summary of microthermometric and Raman spectroscopy data for Lw and Lwh fluids from the breccia cement, geodic quartz and calcite veins. nd: not determined, $\mathrm{nm}$ : not measured, Tm ice : melting temperature of ice, $\mathrm{Tm}$ halite : melting temperature of halite, $\mathrm{TH}:$ homogenization temperature. .

\begin{tabular}{|c|c|c|c|c|c|c|c|c|c|c|c|}
\hline Location & Sample description & Sample & Mineral & Fl type & Tm ice ('c) & $\mathrm{TH}\left(\mathrm{C}^{\circ} \mathrm{C}\right)$ & Tm halite ("C) & $\begin{array}{c}\text { Salinity } \\
\text { wto Nacl equiv. }\end{array}$ & 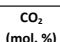 & \begin{tabular}{|c|c|}
$\mathrm{CH}_{4}$ \\
$($ molo.
\end{tabular} & \begin{tabular}{|c|c|}
$N_{2}$ \\
(mol.o.
\end{tabular} \\
\hline \multirow[t]{3}{*}{ Col d'Etche } & Breccia cement & Etche $4 C$ & Quartz & $\operatorname{Lw}_{\text {Lwh }}$ & -7.6 to -20.3 & $\begin{array}{l}190.6 \text { to } 278 \\
165.4 \text { to } 178.1\end{array}$ & 196.2 to 233.8 & $\begin{array}{l}11.2 \text { to } 22.5 \\
32 \text { to } 33.8\end{array}$ & 13 & 87 & nd \\
\hline & Breccia cement & Etche 5 & Quartz & $\operatorname{Lwh}_{\text {Lwh }}$ & -7.5 to -21.2 & $\begin{array}{c}219.5 \text { to } 276.4 \\
195.2\end{array}$ & 205.2 & $\underset{31 \text { to } 23}{12.2}$ & 0 to 5 & 8 to 100 & \begin{tabular}{|l|}
0 to 92 \\
\end{tabular} \\
\hline & Geodic quartz & Etche 4A & Quartz & Lwh & & 167.5 to 204.9 & $\begin{array}{l}196.2 \text { to } 254.9 \\
\text { 2outtiers } 175.6 \text { and } 277.6\end{array}$ & 30.7 to 36.5 & 0 to 25 & 43 to 90 & \begin{tabular}{|l|l|}
0 to 60 \\
\end{tabular} \\
\hline Urdach & $\begin{array}{l}\text { Calcite and serpentine- } \\
\text { chlorite exins }\end{array}$ & URD E & Calcite & monophase & $\mathrm{nm}$ & $\mathrm{nm}$ & $\mathrm{nm}$ & 1 & nd & nd & nd \\
\hline
\end{tabular}




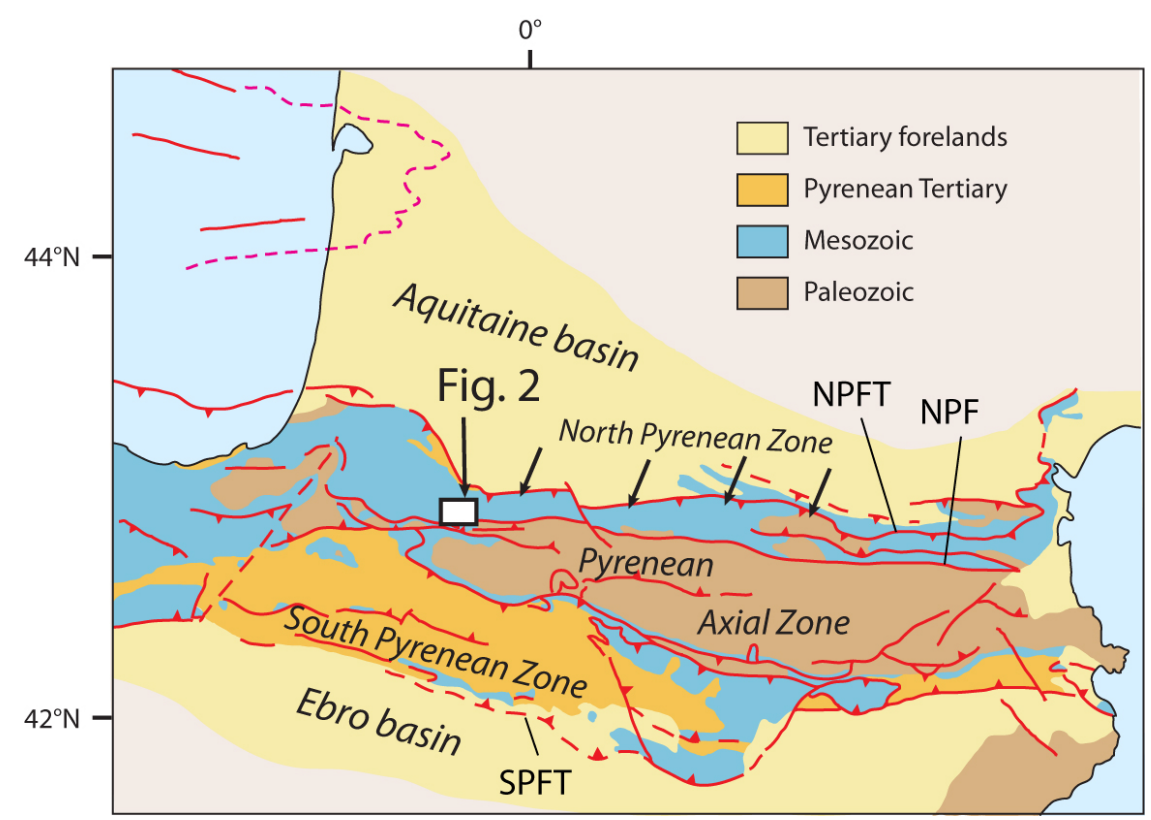

Figure 1 


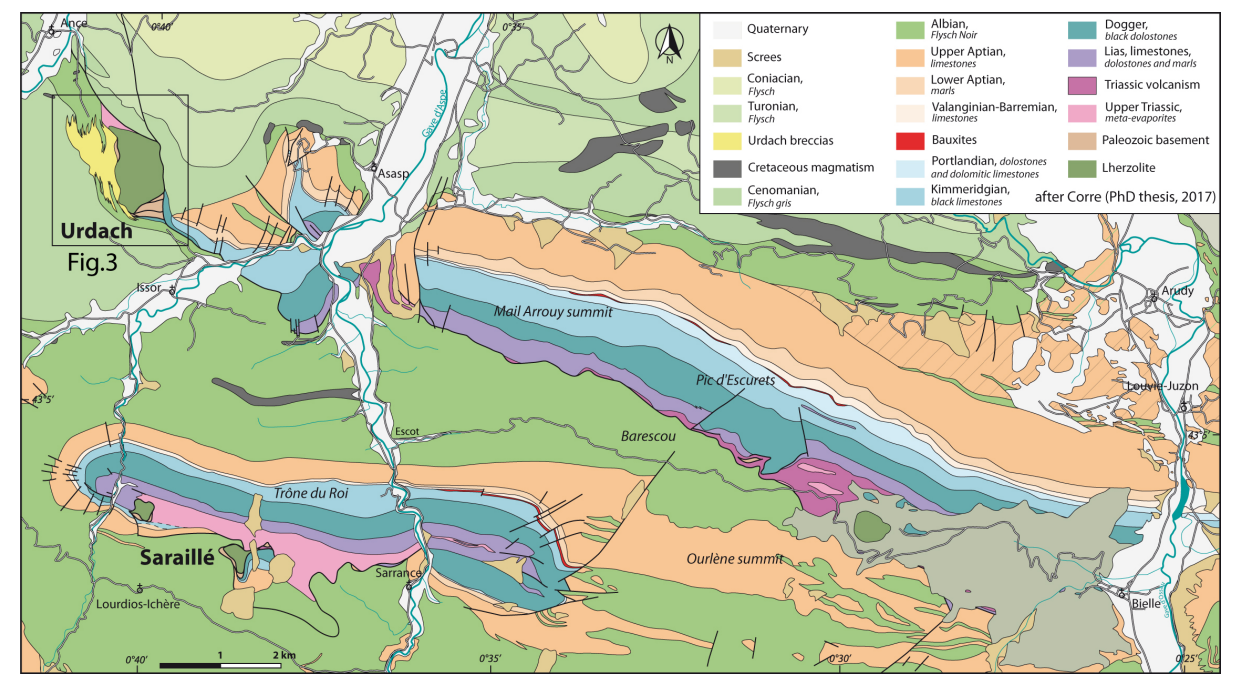

Figure 2 

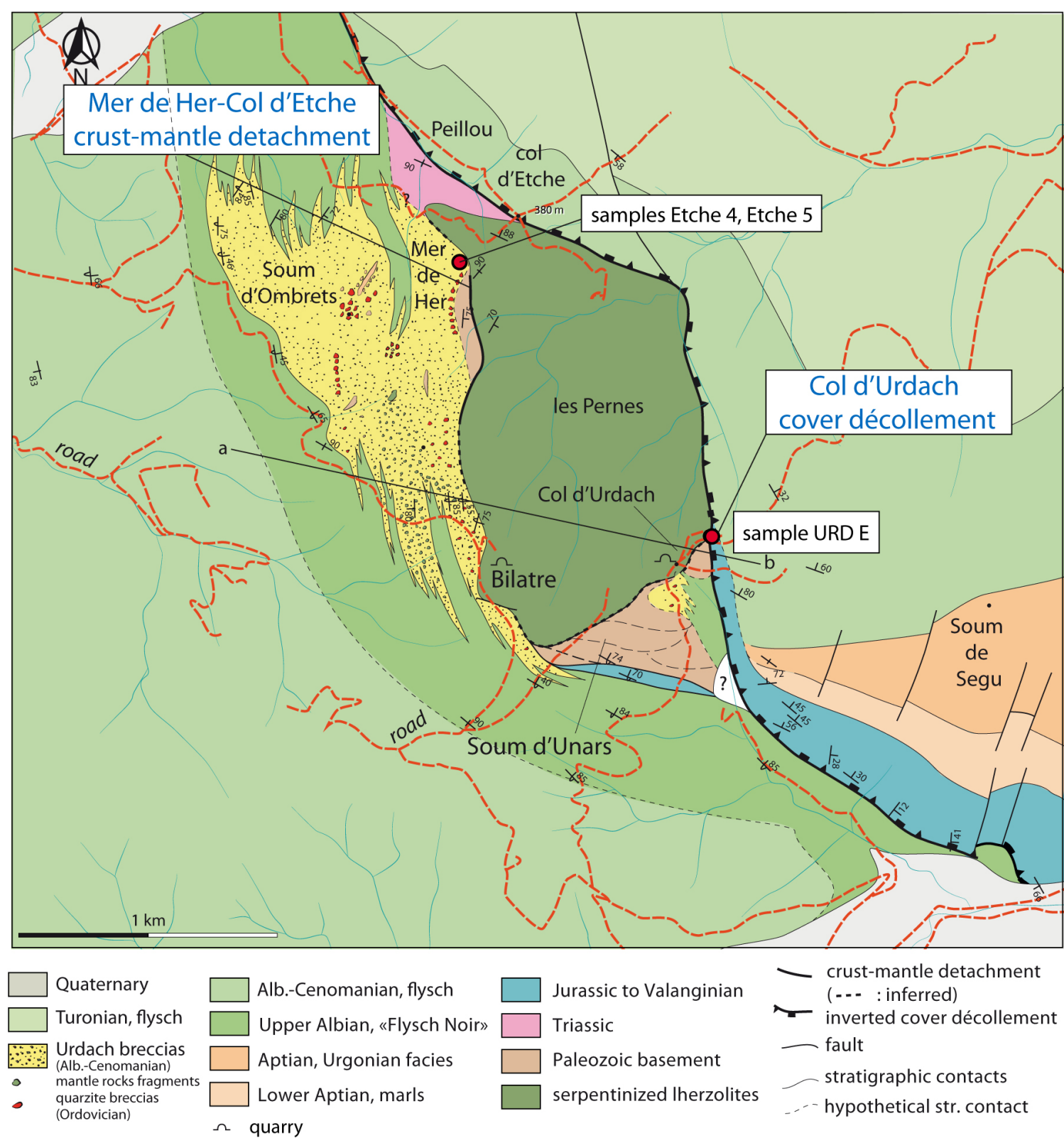

- quarzite breccias $\Omega$ quarry crust-mantle detachment- - -

\section{cover décollement}

a

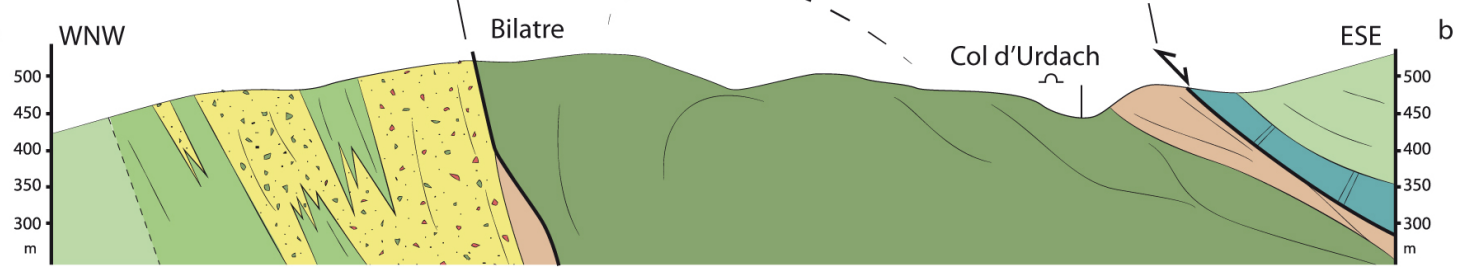

Figure 3

modified after Lagabrielle et al. (2019a) 

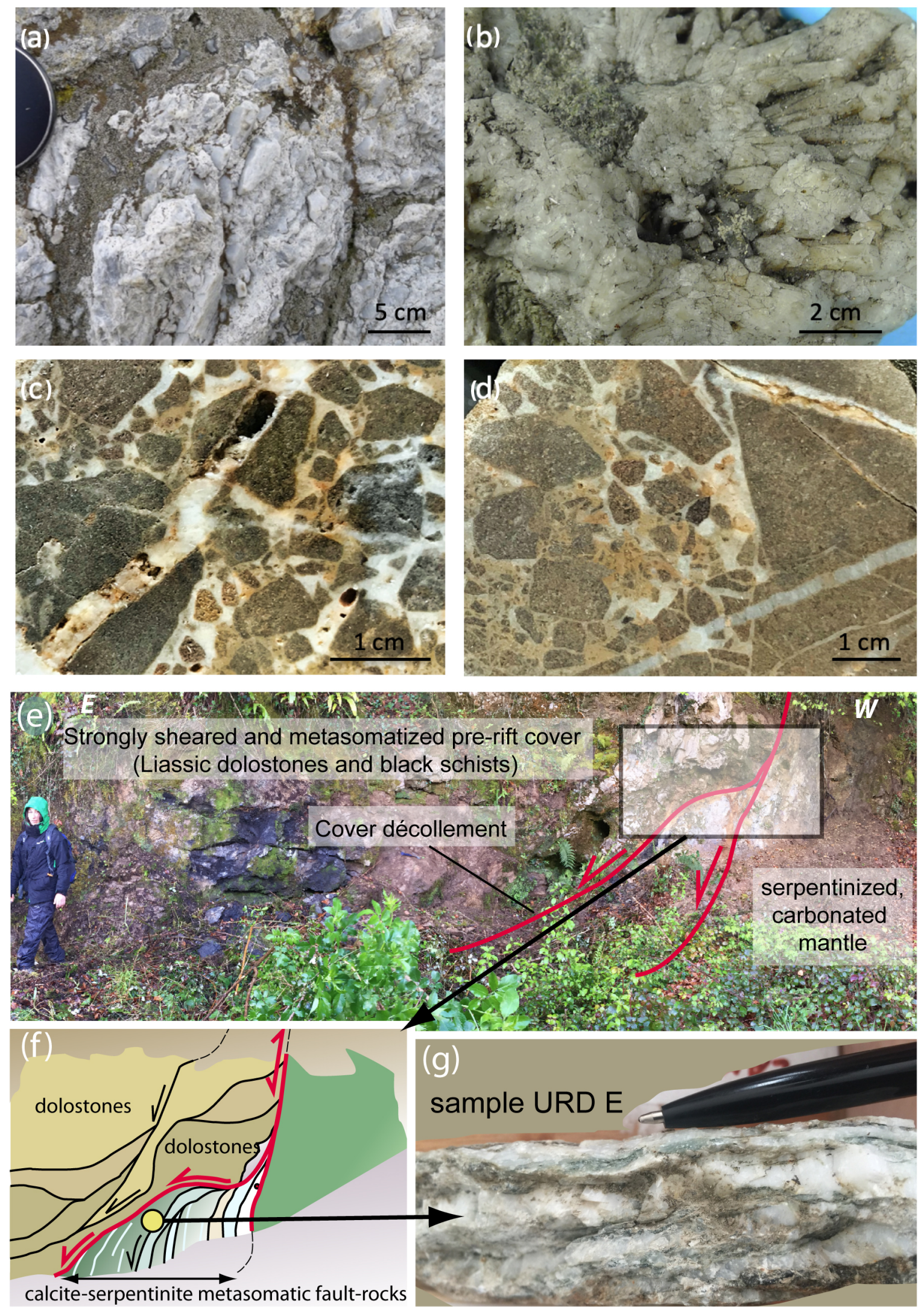

Figure 4 


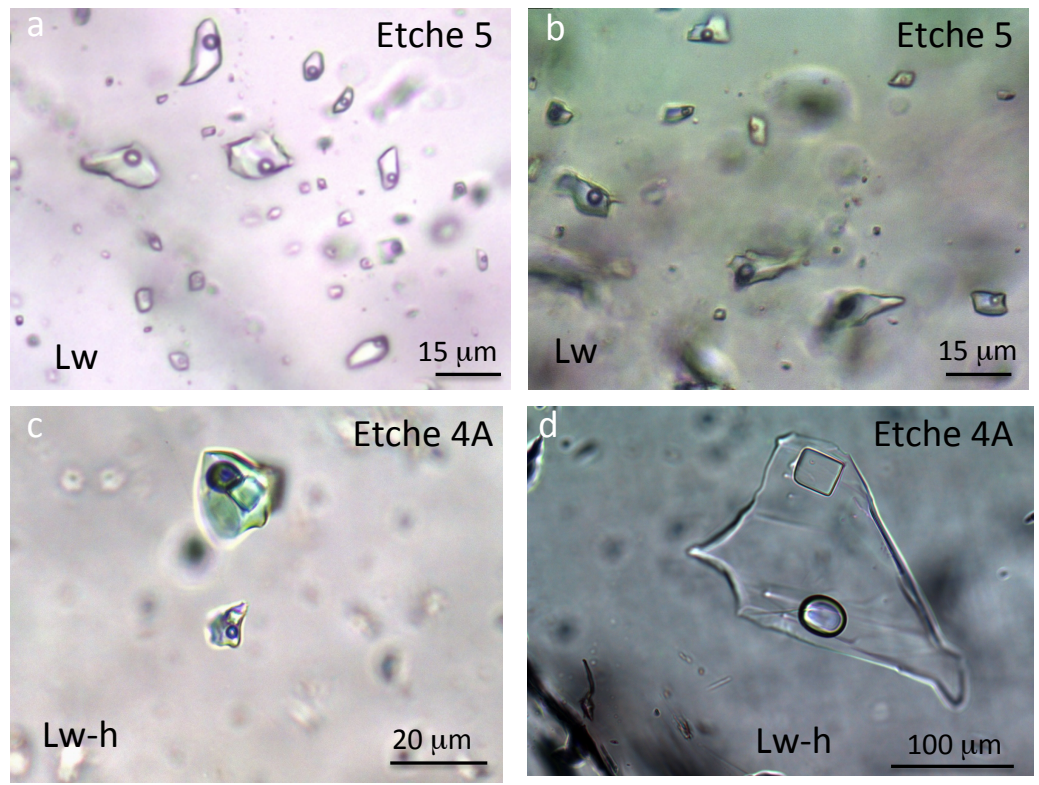

Figure 5 

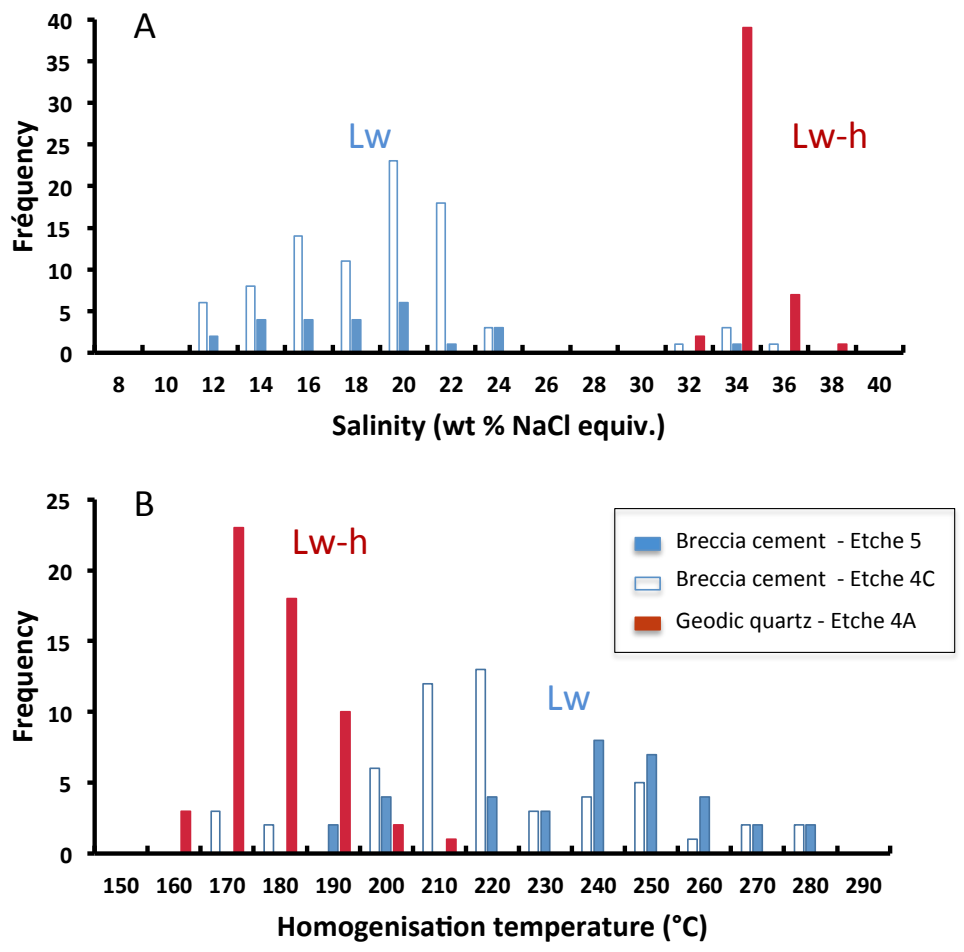

Figure 6 


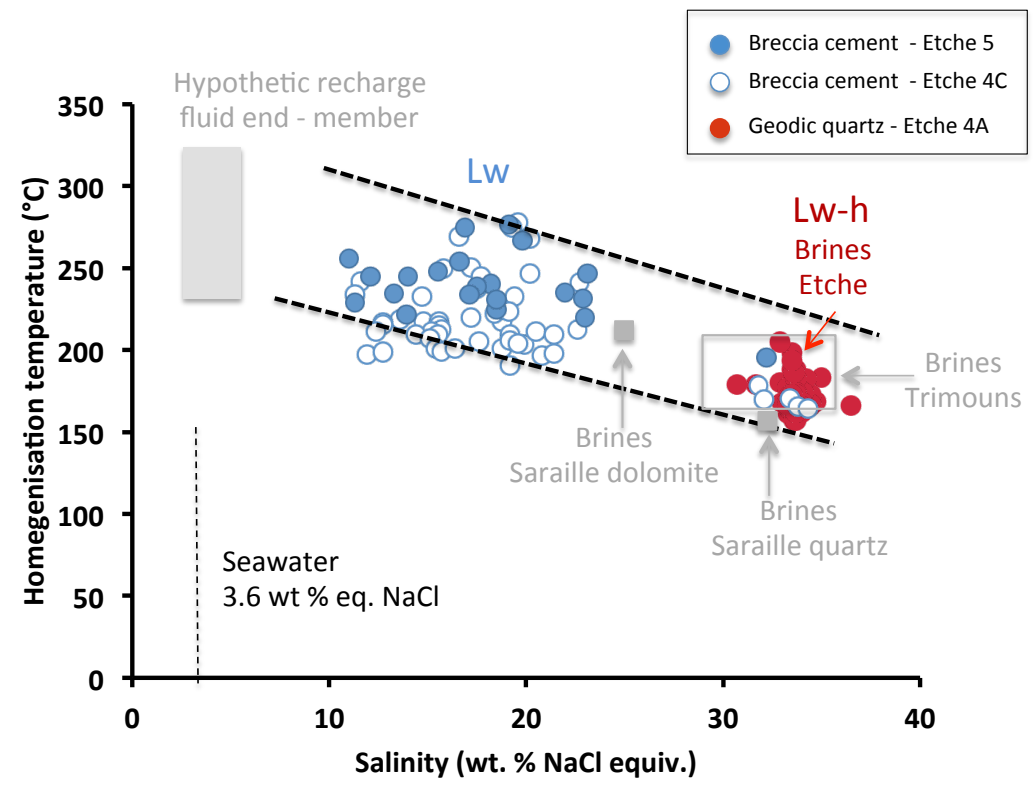

Figure 7 


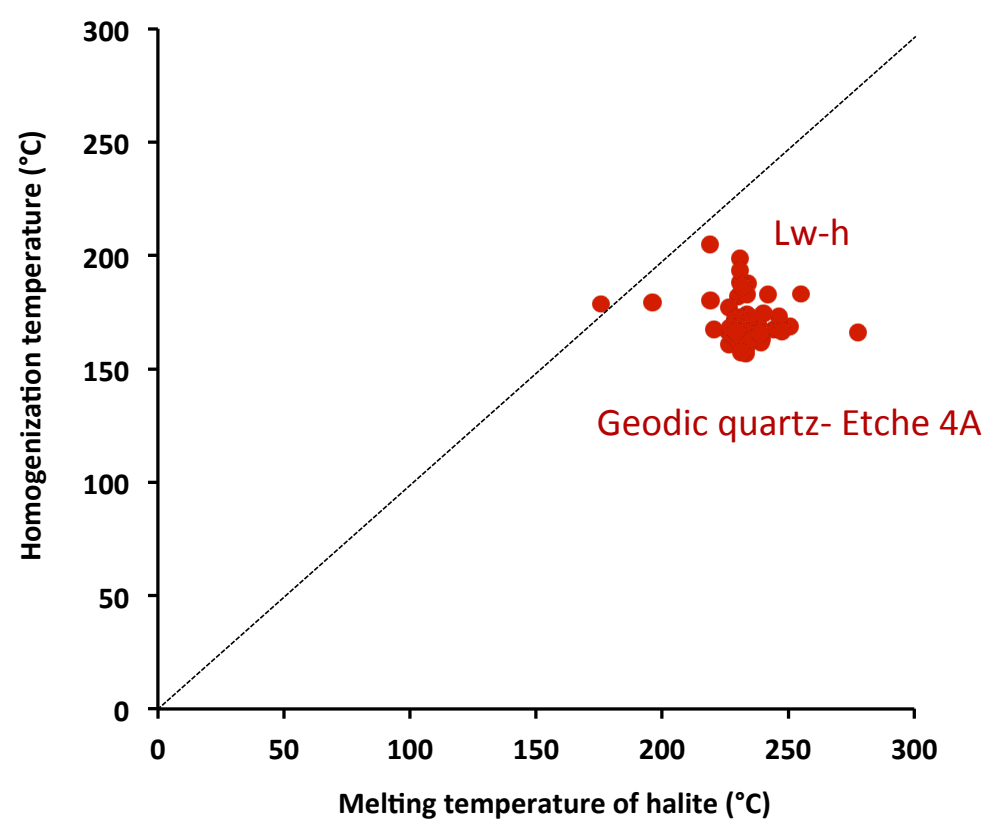

Figure 8 


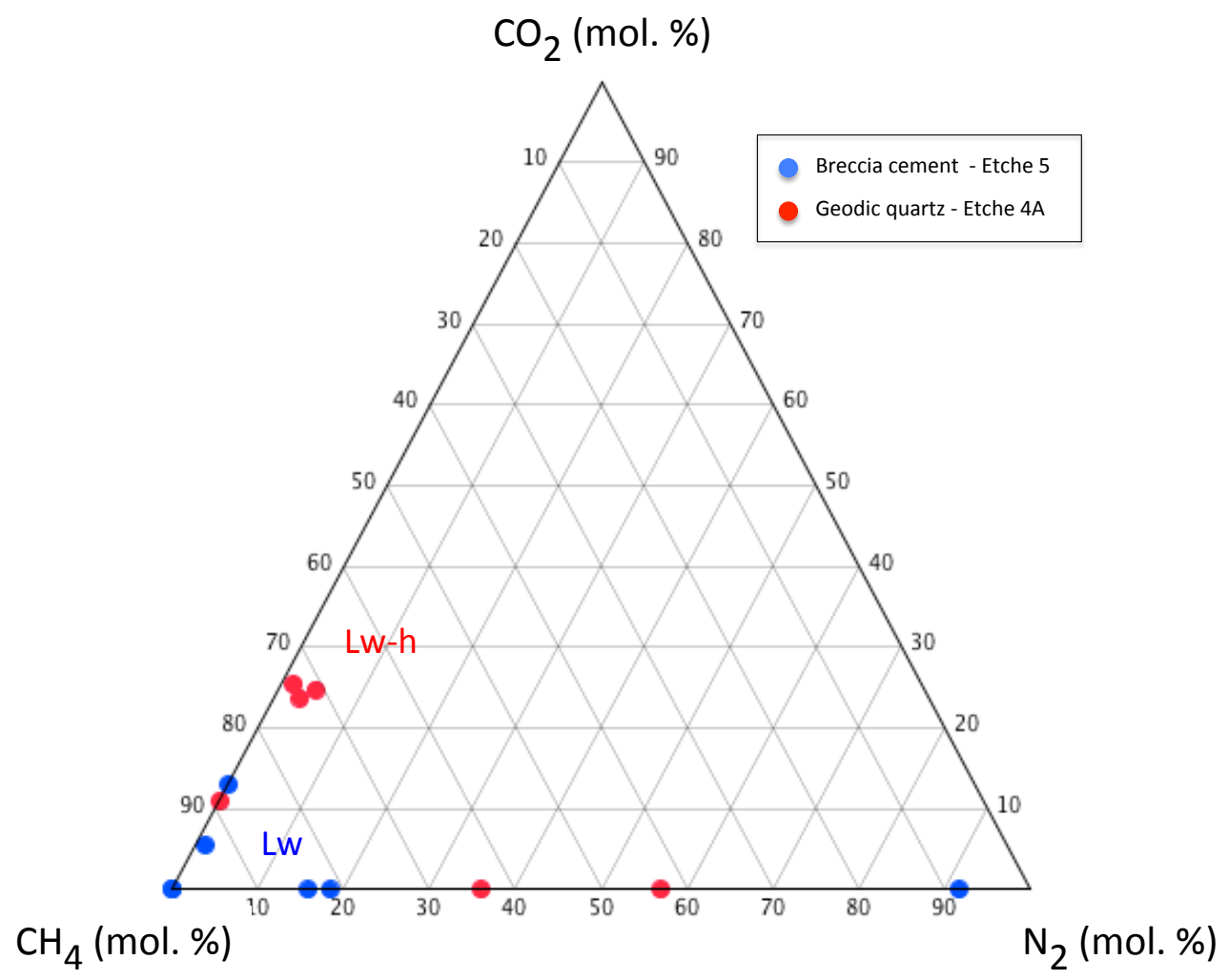

Figure 9 


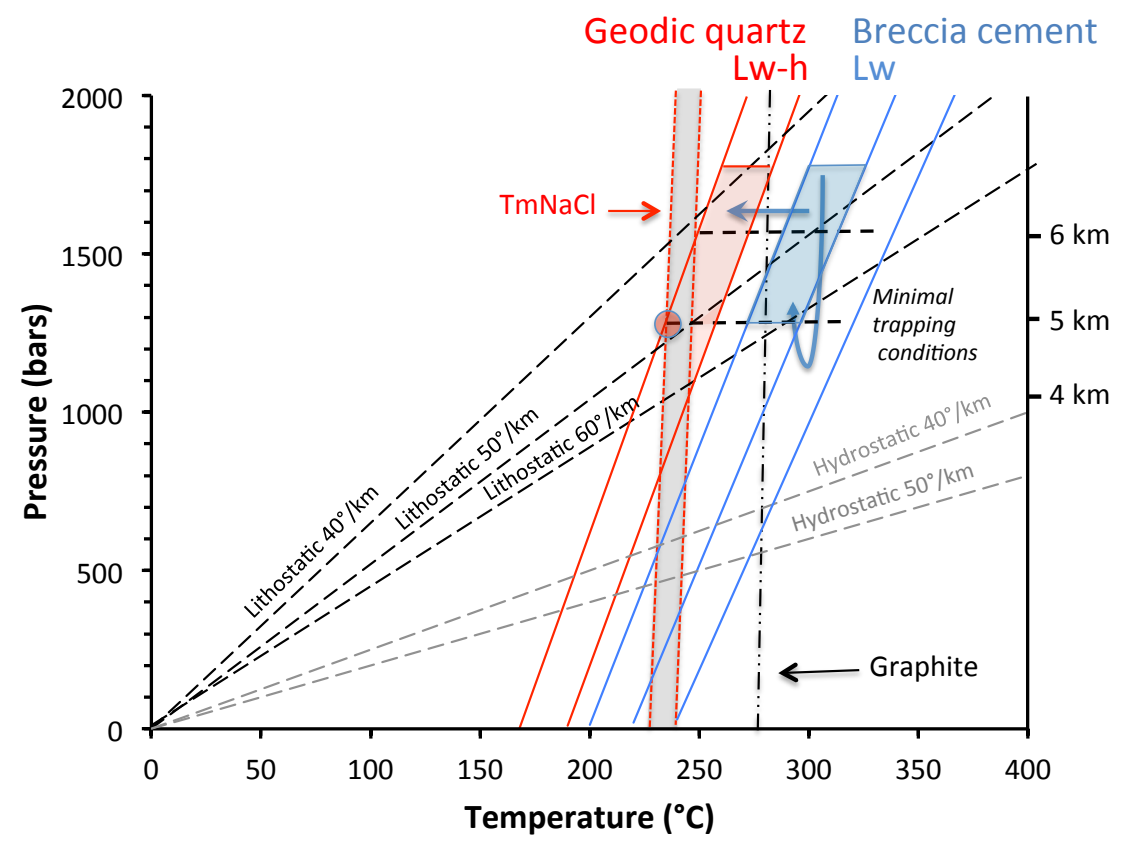

Figure 10 


\section{IBERIA MARGIN}

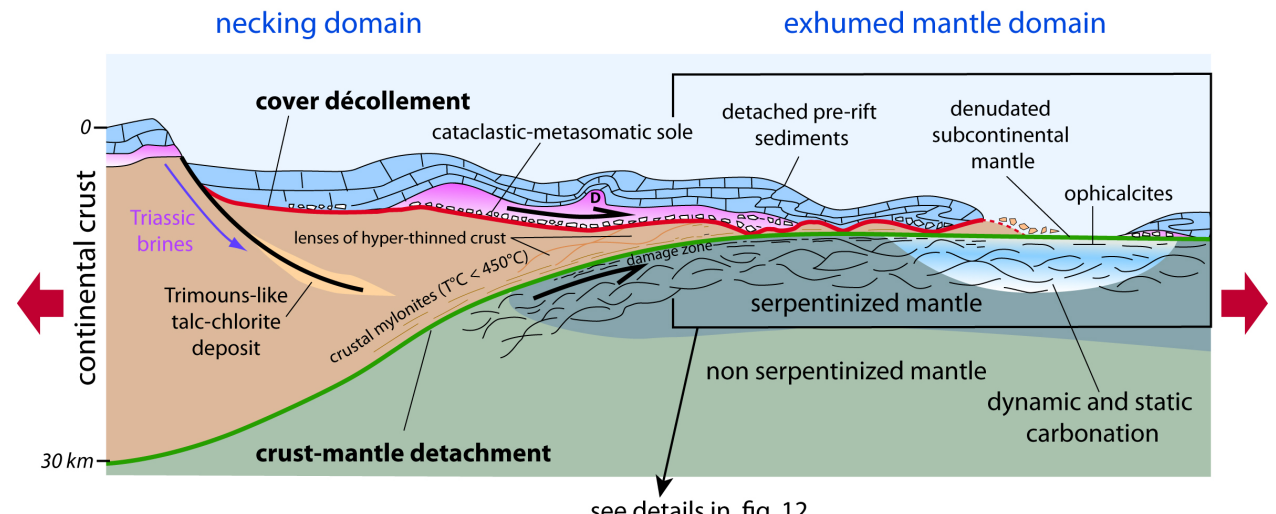

Figure 11 


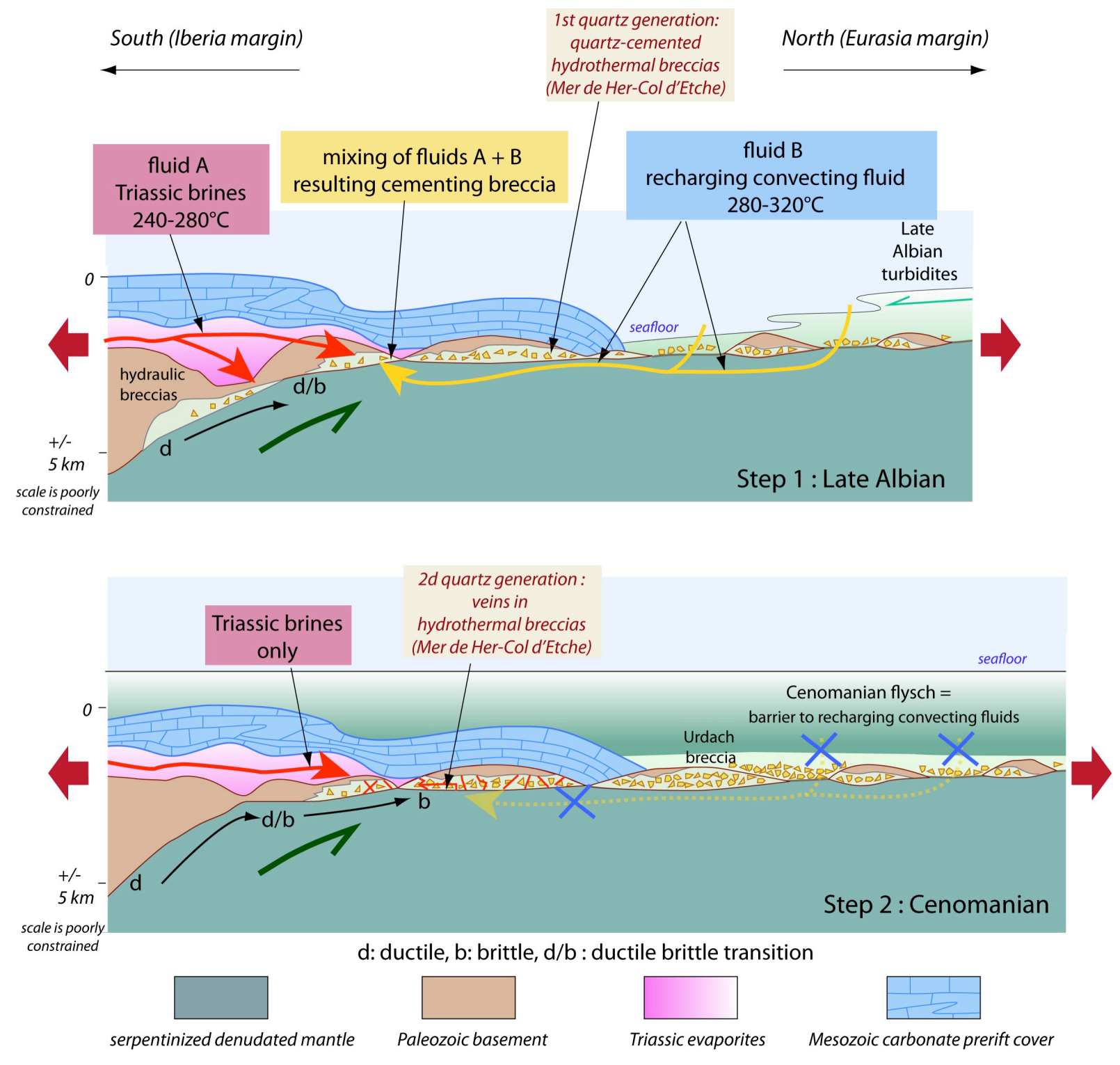

Figure 12 